\title{
Clay mineralogy and thermal history of the Neogene Vinchina Basin, central Andes of Argentina: Analysis of factors controlling the heating conditions
}

\author{
Gilda Collo, ${ }^{1}$ Federico M. Dávila, ${ }^{1}$ Julieta Nóbile, ${ }^{1}$ Ricardo A. Astini, ${ }^{1}$ \\ and George Gehrels ${ }^{2}$ \\ Received 16 November 2010; revised 16 May 2011; accepted 31 May 2011; published 25 August 2011.
}

[1] The Vinchina Foreland Basin, western Argentina, contains a $\sim 7 \mathrm{~km}$ thick nonmarine stratigraphy, chronologically constrained within the Mio-Pliocene (circa 19-3.4 Ma), and where distribution of Illite/Smectite interstratified phases has shown a progressive smectite-illitization progress $(\mathrm{R} 0 \rightarrow \mathrm{R} 1 \rightarrow \mathrm{R} 3)$, is consistent with an incipient burial history. R0 represents randomly mixed-layered illite/smectite normally found at shallow depths, as this ordering is not stable at $\sim 120^{\circ} \mathrm{C}$. In the Vinchina Basin, however, the R0 is still persistent at $\sim 7 \mathrm{~km}$ depth, and its appearance even in the deepest levels is consistent with previous interpretations of low burial temperatures based on thermochronologic studies of detrital apatites. The maximum paleotemperature estimation and basin depth imply geothermal gradient as low as $\sim 15^{\circ} \mathrm{C} / \mathrm{km}$, which allowed an estimate of heat flow values between 33 and $42 \mathrm{~mW} / \mathrm{m}^{2}$, that would rise to between $\sim 40$ and $51 \mathrm{~mW} / \mathrm{m}^{2}$ when the sedimentation rate (thermal blanketing) is taken into account. These values were only reported for cold basins and represent a paleothermal state of a refrigerated lithosphere. We suggest the central Andes were dominated since the Miocene by heat transfer derived mostly from crustal contributions with a minimum input from the asthenosphere. This refrigerated lithosphere is typical of segments affected by flat subduction. Preliminary thermal models based on previous geodynamic approaches support our conclusions.

Citation: Collo, G., F. M. Dávila, J. Nóbile, R. A. Astini, and G. Gehrels (2011), Clay mineralogy and thermal history of the Neogene Vinchina Basin, central Andes of Argentina: Analysis of factors controlling the heating conditions, Tectonics, 30 , TC4012, doi:10.1029/2010TC002841.

\section{Introduction}

[2] The crustal geothermal gradient is an important factor in the evolution and maturity of sedimentary basins and provides information about the tectonic setting and thermal events that have affected a sedimentary fill. The thermal modeling of ancient sedimentary basins requires, among other geological data, an estimate of the past heat fluxes and calculation of the paleotemperatures and conductivity changes with depth and time. To do this we need to combine various proxies for past heat flow as well as numerical modeling [e.g., Husson and Moretti, 2002]. From Fourier's law, temperature gradient in boreholes and the thermal conductivity are required in order to estimate heat flux [Turcotte and Schubert, 2002].

[3] Three different approaches have been used in thermal modeling of sedimentary basins: vitrinite reflectance, mineralogical and color indexes, and radiometric dating (ther-

\footnotetext{
${ }^{1}$ Laboratorio de Análisis de Cuencas, CICTERRA-Universidad

Nacional de Córdoba, Córdoba, Argentina.
${ }^{2}$ Department of Geosciences, University of Arizona, Tucson, Arizona, USA.

Copyright 2011 by the American Geophysical Union. 0278-7407/11/2010TC002841
}

mochronology) [Allen and Allen, 2005]. Because most continental alluvial red-bed successions, like those along the Andean foreland, do not preserve organic matter and radiometric dating is useful only between certain activation temperatures, mineralogical approaches are likely the better and more accurate method to study foreland basins thermal evolution. Exploring mineralogical indexes, particularly those of clay minerals, can be applied to detrital sequences in order to determine basin maturity and geothermal gradients during diagenesis [e.g., Hower et al., 1976; Merriman and Peacor, 1999]. For example, the progressive transformation of smectite to illite (illitization) causes the illite/ smectite (I/S) ratio to increase as burial temperature increases so the I/S ratio for a sedimentary record allows an estimate of the paleotemperatures reached by a basin during its burial history. The estimation of the paleothermal conditions in a sedimentary basin can, in turn, help to understand the geodynamic setting.

[4] There is an absence of data for geothermal gradient, whether modern or ancient, in the sierras Pampeanas region. In that absence, various previous studies [e.g., Jordan et al., 1989; Sobel and Strecker, 2003; Carrapa et al., 2008; Löbens et al., 2011] have assumed a conservative average values of $20^{\circ}-30^{\circ} \mathrm{C} / \mathrm{km}$ for the Mio-Pliocene geotherm. 


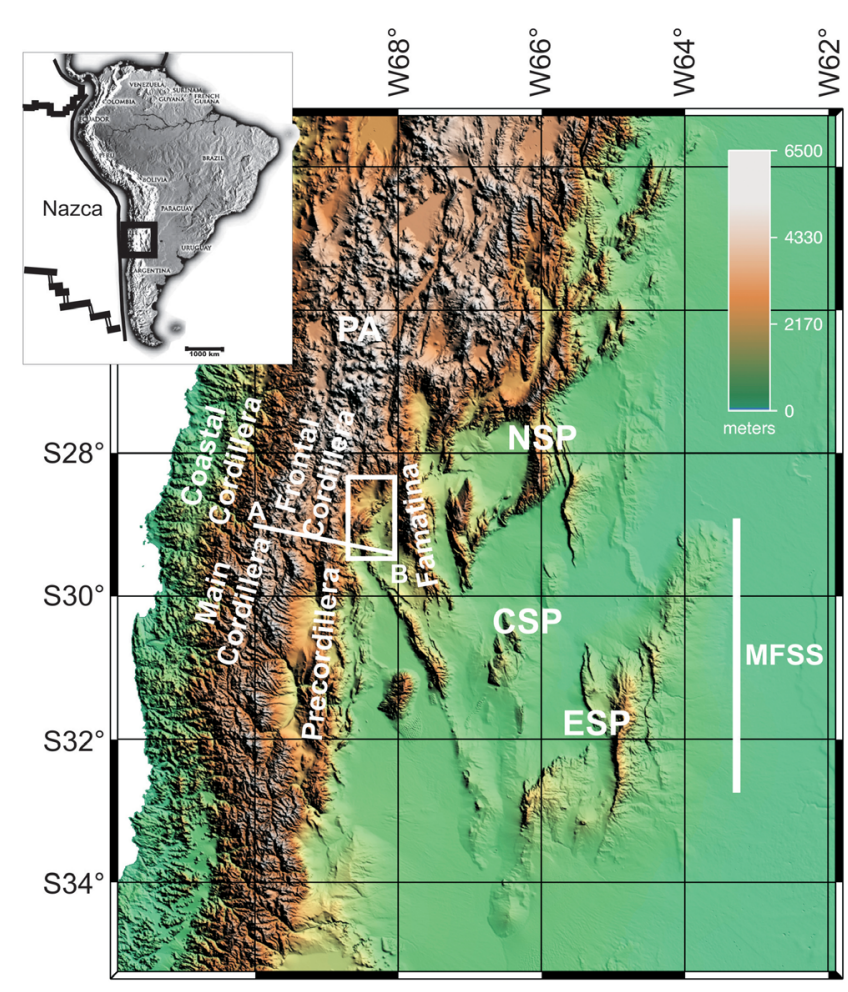

Figure 1. Shaded topographic relief image (U.S. Geological Survey), showing the Central Andean Foreland of Argentina. The Precordillera, Frontal Cordillera, Main Cordillera, Coastal Cordillera, and Puna Austral (PA) are shown for regional reference. The areas affected by the modern flat-slab segment (MFSS) are shown [after Barazangi and Isacks, 1976]. B, Bermejo Basin; NSP, northern Sierras Pampeanas; CSP, central Sierras Pampeanas; ESP, Eastern Sierras Pampeanas. The white rectangle shows the location of Figure 2. Modified from Dávila and Astini [2007]. White solid line A-B shows the location of the cross section in Figure 3.

Available regional heat flow data [Muñoz and Hamza, 1996; Springer and Förster, 1998; Hamza et al., 2005] and gradients generated by modeling different basin settings served as the main sources of information. Because of the extraordinary depths of some foredeeps along the Andean foreland, bottom temperatures in the anchizonal field (200 $300^{\circ} \mathrm{C}$ ) should be expected if those assumed gradients were correct. However, deep basins in the Andes ( $>5 \mathrm{~km}$ thick) do not record features indicating intense diagenesis; and the detrital apatite fission track (AFT) ages show a wide dispersion without significant postdepositional annealing [Coughlin, 2002; Coutand et al., 2006; Carrapa et al., 2006] suggesting the bottom of the synorogenic successions never reached the maximum apatite fission track annealing temperature $\left(120^{\circ} \mathrm{C}\right)$ [cf. Gleadow and Duddy, 1981; Naeser, 1979, 1981].

[5] In order to determine the burial history of the Central Andean foreland of Argentina (Figure 1) and estimate the Mio-Pliocene paleogeothermal gradient for this region, we evaluated the progressive illitization processes in one of the thickest foredeep depocenters known in the Andes, the
Vinchina Basin ( $28^{\circ}$ SL; Figure 2). This basin contains a largely uninterrupted Miocene to Pliocene record of fine to coarse-grained synorogenic strata locally greater than $>12 \mathrm{~km}$ thick.

[6] Preliminary results [Nóbile et al., 2008; Collo and Dávila, 2008] showed that burial diagenesis and paleogeothermal gradients were not consistent with the aforementioned conservative average geothermal gradients. These results are fully presented and discussed in this contribution. Moreover, our study evaluates alternative causes of refrigeration in the basin, including tectonic scenarios. Relations between interstratified clay mineral distribution and temperature permit an estimate of the diagenetic history and the maximum burial temperature reached for the sequence. New $\mathrm{U}-\mathrm{Pb}$ detrital zircon ages are herein used to better constrain depositional age and provenance of the basin which helps reconstruct its depositional-burial-exhumation history and geodynamic setting.

\section{Geological Setting}

[7] The Los Colorados range, immediately west of the town of Vinchina in La Rioja Province (Figure 1) is composed of an extraordinarily thick and continuous alluvial synorogenic succession. The outcrop belt is interpreted to be a thrust-related extrusion of the Neogene Vinchina Basin [Turner, 1964; Ramos, 1970] (Figures 2a and 3). The subsidence of the basin has been traditionally related to an intense topographic loading occurred in the High Andes since the early Miocene [Cardozo and Jordan, 2001]. Nevertheless, recent flexural modeling has not been able to reproduce this enormous thickness and alternative sublithospheric mechanisms were invoked (e.g., dynamic topography) [Dávila et al., 2005, 2007, 2010]. Two formations were described in this range: the Vinchina and the Toro Negro Formations. The Vinchina Formation $(\sim 4.7 \mathrm{~km})$ is composed of a succession of predominantly red sandy conglomerate strata interspersed with thin levels of mudstone and tuff. The Toro Negro Formation $(\sim 2.4 \mathrm{~km})$, consists of a thick sequence of alluvial amalgamated conglomerates with alternating sand levels at the base of the unit [Ramos, 1970]. Upper Pliocene to Pleistocene flat lying conglomerates (known as Punashotter conglomerates further north [Carrapa et al., 2006, 2008] cover both formations with angular discordance (Figure 2b). Although these stratigraphic relationships come from the Sierra de Los Colorados, they can also be traced further north to the latitude of the Toro Negro range and to the south into the Umango-Punilla ranges, (Figure 2a), where crystalline basement crops out at the base of the section as part of the broken foreland of western Argentina. According to various isotopic, paleogeographic and magnetostratigraphic studies, the Vinchina and Toro Negro Formations at Sierra de los Colorados accumulated between the Early Miocene and Pliocene [Tabbutt, 1986; Tabbutt et al., 1989; Re and Barredo, 1993; Ciccioli et al., 2005; Rodríguez Brizuela and Tauber, 2006]. Particularly magnetostratigraphic studies [Re and Barredo, 1993] through this thick stratigraphy and zircon fission track analysis on various tuffs constrained by Tabbutt [1986], bracketed the sedimentation history of the basin between $\sim 18 \mathrm{Ma}$ and $\sim 3.4 \mathrm{Ma}$ (Figure $4 \mathrm{a}$ ). 


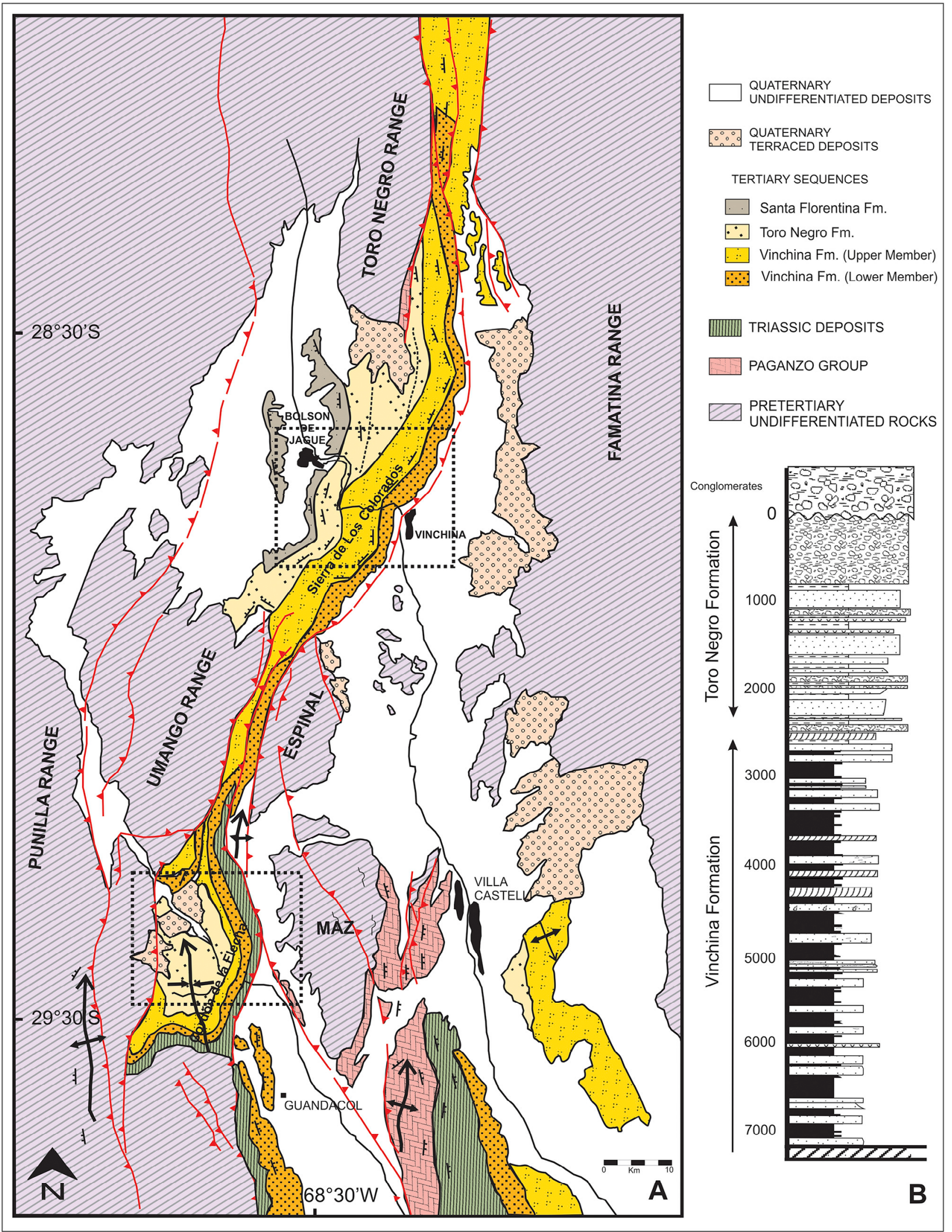

Figure 2. (a) Geological map from the western region of the La Rioja Province, showing the distribution of the Tertiary deposits within the Vinchina Basin (modified from Ramos [1999]). Dashed line boxes show location of the studied transects. (b) Representative stratigraphic column of the basin at Sierra de los Colorados section; the Vinchina and Toro Negro Formations are distinguished (modified from Ramos [1970]. 


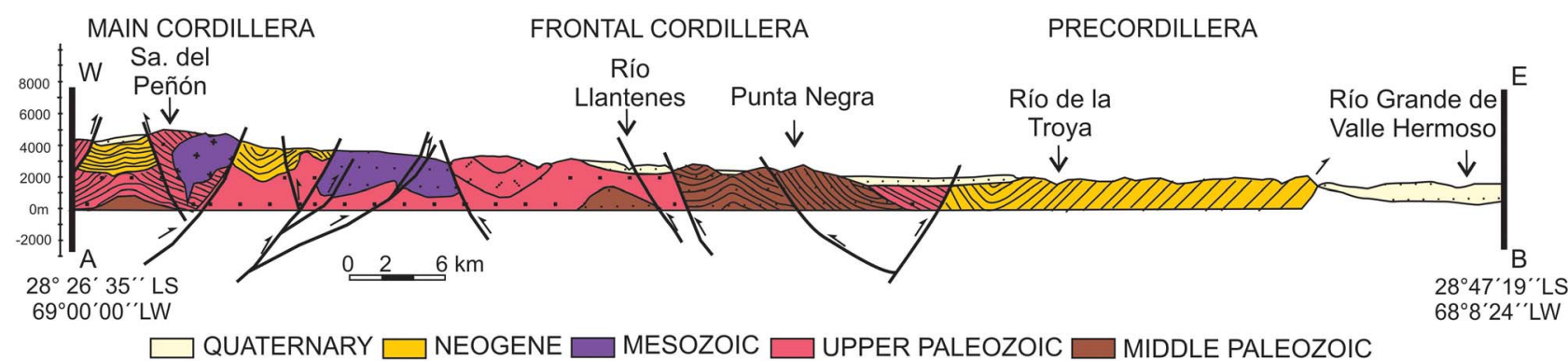

Figure 3. Regional cross section (A-B) [from Fauque and Caminos, 2006]. See the location in Figure 1.

[8] Subhorizontal conglomerates unconformably covering the Vinchina and Toro Negro formations at Sierra de los Colorados indicate that the exhumation and truncation of the Vinchina Basin strata occurred after 3.4 Ma (youngest age of Toro Negro Fm). Although no radiometric ages are available for the undeformed conglomerates in the study area, equivalent units to the northeast were recently dated between 3.77 and 3.05 Ma (Punashotter conglomerates) [Carrapa et al., 2008]. To the east (Santa Florentina Formation), similar conglomerates were biostratigraphically constrained to the Plio-Pleistocene [Lencinas, 1994]. These ages indicate that the Vinchina Basin strata would have remained only a relatively short time (less than 1 million years) at maximum burial conditions.

[9] In the Cordón de La Flecha, Tertiary strata (Figure 2a) have an approximate thickness of $\sim 6 \mathrm{~km}$ [Furque, 1972; Reynolds et al., 1990]. In this section, strata correlated with the Vinchina Formation ( $\sim 3.2 \mathrm{~km}$ thick) rest on the lower to middle Miocene eolian beds of the Vallecito Formation ( $\sim 1.2 \mathrm{~km}$ thick) [Borrello and Cuerda, 1968; Jordan et al., 1993]. The Zapallar Formation ( 1.6 km thick) overlies the Vinchina Formation and correlates lithostratigraphically with the Toro Negro Formation exposed further north. This is a typical progradational, coarsening-upward alluvial sequence formed by playa lake deposits at the base and thick and coarse conglomerates at its top [Reynolds et al., 1990]. Magnetostratigraphic data complemented with zircon fission track analyses on a tuff located at $2.3 \mathrm{~km}$ from the base of the Vinchina Formation [Tabbutt, 1986; Reynolds et al., 1990], indicate that the nonmarine strata at this section span between $\sim 18$ and $\sim 9 \mathrm{Ma}$. The contact between the Vinchina and Zapallar Formations would locate at approximately 12 to $12.5 \mathrm{Ma}$. The overall constraints previously stated support previous arguments that filling of the basin was highly diachronous along strike [Ramos et al., 1988]. More recent whole-rock $\mathrm{K}$-Ar studies suggest a wider interval of ages ranging from Eocene-Oligocene for the basal sections of Cordón de La Flecha [Tedesco, 2006], to Late Miocene for the uppermost levels of Sierra de los Colorados section [Ciccioli et al., 2005, 2008]. Nonetheless, the tuffaceous beds of the Vinchina basin display a high degree of detrital recycling from older units [Dávila et al., 2008], so whole-rock geochronology needs to be analyzed accordingly.

[10] The broad stratigraphic evolution of the central Andean foreland basin was divided into three major stages [cf. Jordan et al., 2001]: two largely asymmetric "simple foreland" [cf. DeCelles and Giles, 1996] stages, beginning at $\sim 20 \mathrm{Ma}$ and $\sim 14 \mathrm{Ma}$, and a younger intermontane scenario driven by foreland partitioning after $\sim 6 \mathrm{Ma}$. This evolution was interpreted from coeval synorogenic successions exposed further south in the Bermejo basin ( 30-29 SL), within and east of the Argentine Precordillera [e.g., Beer and Jordan, 1989; Jordan et al., 1993]. The depositional history at the Vinchina Basin might have been somewhat different than the general picture. An intermontane accumulation scenario was suggested by the uplifting of the Famatina basement ranges to the east since the early middle Miocene [Dávila and Astini, 2007; Zambrano et al., 2011]. This protracted intermontane scenario likely triggered development of relatively narrow and deep depocenters acting as sediment sinks [Dávila and Astini, 2003a, 2003b].

\section{Theoretical Framework}

[11] The proportion of smectite (S) in I/S has been observed to decrease with depth and the changes of I/S with temperature have been well constrained in basins where the modern geothermal gradient is known [e.g., Sucha et al., 1993]. The series involving dioctahedral clay minerals is smectite that converts to mixed-layer illite/smectite, which converts to illite. Under high-geothermal gradients, $>40^{\circ} \mathrm{C} / \mathrm{Km}$ (e.g., South Central Texas basin [Velde and Vasseur, 1992; Awwiller, 1993]), the $\mathrm{S}$ content in $\mathrm{I} / \mathrm{S}$ decreases sharply with depth (less than $50 \%$ at $2500 \mathrm{~m}$ depth). In basins with a lowthermal gradient, $<25^{\circ} \mathrm{C} / \mathrm{Km}$ (e.g., Shimiogarshi and Los Angeles basins [Velde and Vasseur, 1992]), a ratio of S in I/S greater than $50 \%$ persists at $\sim 5000 \mathrm{~m}$ depth).

[12] Most of the studies related to smectite illitization are based on XRD analyses. They describe the I/S interestratified clays present in interlayer arrangements from random (R0) to short-range ordered (R1), to long-range ordered (R3), where $\mathrm{R}$ is the Reichweite parameter [Jagodzinski, 1949] and the I contents in the I/S are between 0 and $50 \%, 50-80 \%$ and $80-100 \%$, respectively. According to literature [e.g., Hoffman and Hower, 1979; Weaver, 1989; Lindgreen, 1991; Pollastro, 1993; Abid et al., 2004], illitization of smectite begins at $\sim 50^{\circ} \mathrm{C}$ and the transition of $\mathrm{R} 0$ to $\mathrm{R} 1$ occurs at $100 \pm 20^{\circ} \mathrm{C}$, whereas R3 develops at higher temperatures.

\section{Methods}

[13] Two transects were systematically sampled through the Los Colorados Range, in the Sierra de los Colorados and in the Cordón de la Flecha $\left(28^{\circ} 43^{\prime} \mathrm{S}, 68^{\circ} 16^{\prime} \mathrm{W}\right.$ and $29^{\circ} 20^{\prime} \mathrm{S}$, 

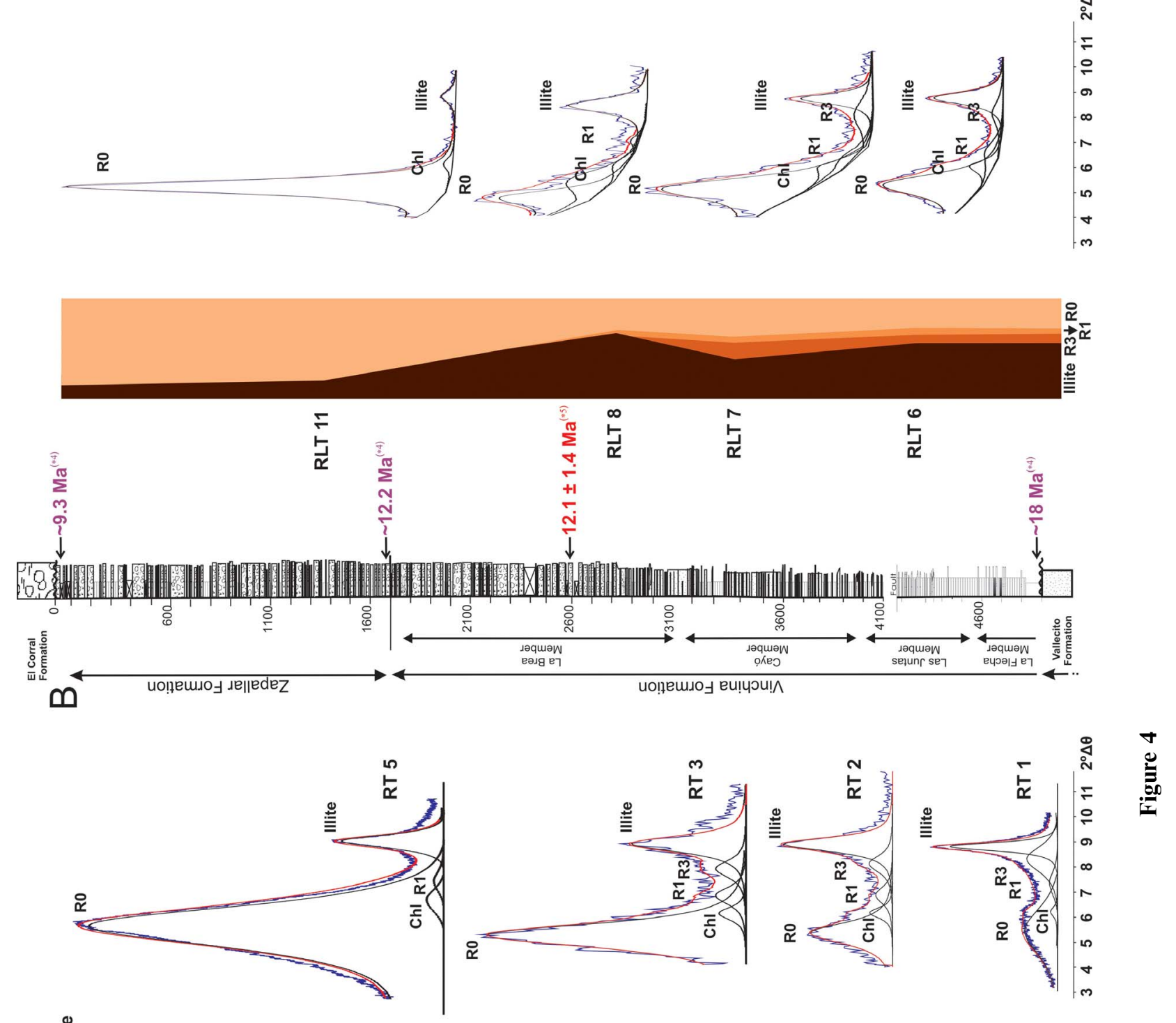

这

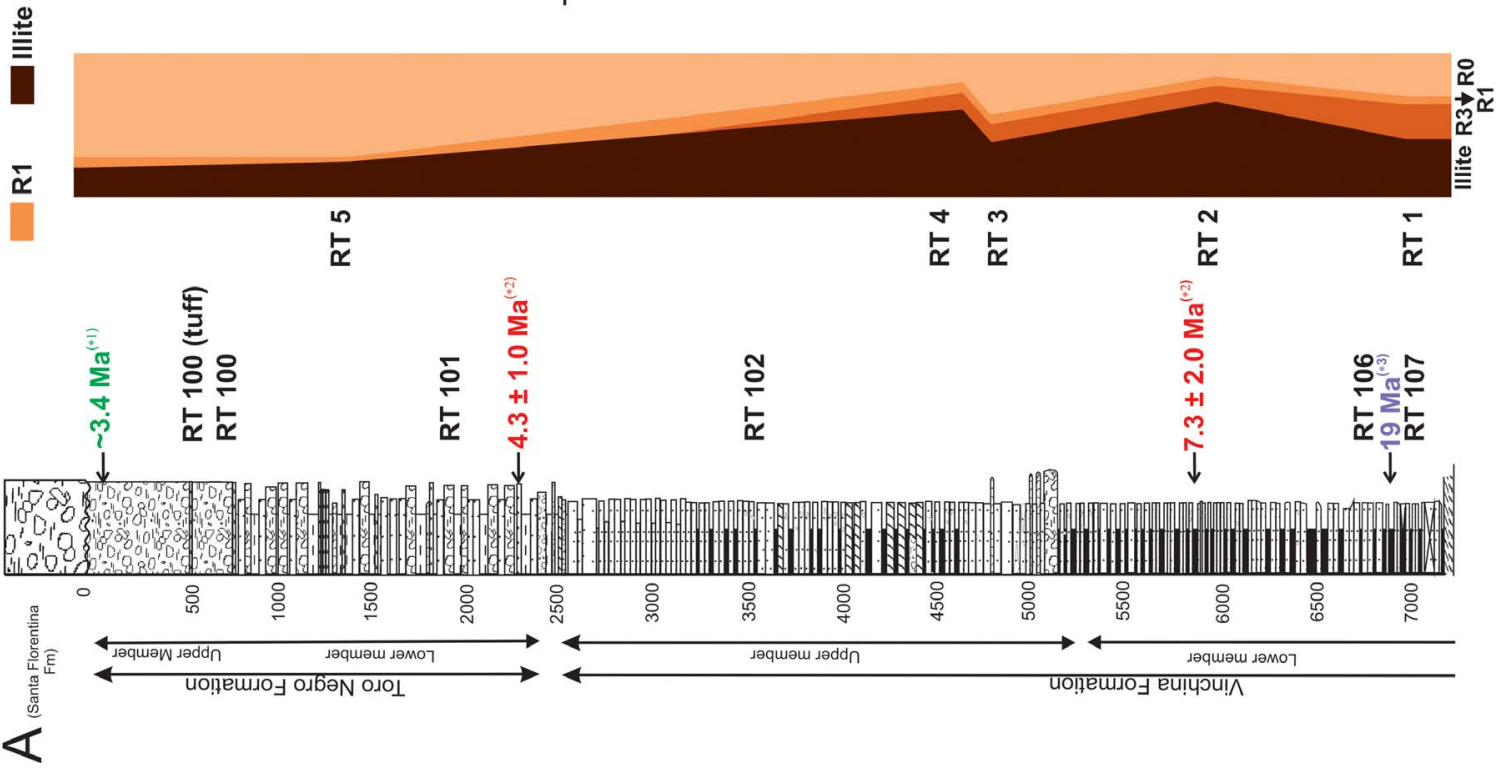


$68^{\circ} 38^{\prime} \mathrm{W}$, respectively; in La Rioja Province) (see auxiliary material). ${ }^{1}$ Specimens of siltstones/mudstones were collected for petrographical and clay mineral analysis. Sampled levels were localized in a stratigraphic column reconstructed on the base of previous studies [Ramos, 1970, Limarino et al., 2001] and our own recent sedimentological surveys [Nóbile et al., 2008]. The column in Figure 2b (Sierra de los Colados section) is transformed into a vertical section, i.e., with zero indicating surface level (as in a borehole) with the maximum thickness of $>7000 \mathrm{~m}$ at the base. This allows easier comparison of our results with borehole data elsewhere and along the Andean foreland (e.g., Bermejo basin) and to run the thermal modeling programs.

[14] Petrographic analyses on thin sections were carried out in order to identify diagenetic features, as grain contacts and cements. The whole-rock mineralogy was determined through X-ray diffraction (XRD) from randomly orientated powders of the bulk sample carried out in an X PANalytical X'Pert PRO diffractometer at the Facultad de Ciencias Químicas, Universidad Nacional de Córdoba (Argentina). Diffraction data were analyzed using Philips X'Pert software coupled to an International Centre for Diffraction Data (ICDD) database. Clay-size mineral phases were identified by XRD in $<2 \mu \mathrm{m}$ fractions of 9 selected samples. Sample runs were made at $40 \mathrm{kV}$ and $40 \mathrm{~mA}, 1 \% \mathrm{~min}$, between 3 and $30^{\circ} 2 \theta$. Samples were prepared following the recommendations of Moore and Reynolds [1997].

[15] Relative proportions of interstratified I/S within the neoformed phases were established from decomposition in the $5^{\circ}-11^{\circ} 2 \theta$ angular interval of XRD patterns of air-dried $(\mathrm{AD})$ and ethilenglycol solvated $(\mathrm{EG})$ routine oriented samples [cf. Lanson and Velde, 1992; Lanson, 1997], using the ProFit1.0c software. Through this process, the presence of interstratified I/S with different proportions of smectite was determined, discriminating the R0, R1 and R3 orderings. Semiquantitative analyses of the interstratified I/S were carried out following the method proposed by Moore and Reynolds [1997].

[16] Two samples located at 1.25 and $7 \mathrm{Km}$ (RT5 and RT1; Figure 4 and auxiliary material) depth were chosen for transmission electron microscope observations in order to characterize clay mineral phases and support XRD data interpretations. Powders were mounted in $\mathrm{Au}$ grids and observations on dispersed grains were carried out with a Philips CM-20 scanning transmission electron microscope (STEM) equipped with an ultrathin window EDX detector (Centro de Instrumentación Científica, C.I.C., Granada University, Spain). Quantitative AEM analyses were obtained from thin edges, using a $1000 \times 200 \AA$ scanning area. Counting times of $15 \mathrm{~s}$ and $100 \mathrm{~s}$ minimized alkali-loss

\footnotetext{
${ }^{1}$ Auxiliary material is available in the HTML. doi:10.1029/ 2010TC002841.
}

problems as short counting times improve reproducibility for $\mathrm{K}^{+}$and $\mathrm{Na}^{++}$[Nieto et al., 1996]. Standards used to obtain the $\mathrm{K}$-factors for the transformation of intensity ratios to concentration, following the methods of Cliff and Lorimer [1975] and Champness et al. [1981], were albite, biotite, spessartine, muscovite, olivine and titanite. The structural formulas were calculated considering 22 negative charges and $0.25 \mathrm{Fe}^{2+} / \mathrm{Fe}^{3+}$ ratio given the presence of iron bearing phases as hematite in most of the samples [cf. Guidotti et al., 1994].

[17] In order to test the influence of the geodynamic scenario in the burial and thermal history of the Vinchina Basin, we used PetroMod 1D Express Basin Modeling (from IES GmbH, Schlumberger) in combination with the geodynamical approaches of Gutscher et al. [2000a] and Yánez et al. [2001]. PetroMod runs numerical simulations involving parameters from each stratigraphic interval such as thickness, lithology and age, defined depositional and erosional events, and fixing paleowater depth (PWD), seawater interface temperature (SWI), and heat flow (HF) values. The HF trend was estimated from the Gutscher et al. [2000a] study, which calculated a thermal evolution for different subduction scenarios. The Gutscher et al. [2000a] scenarios treat the subduction angle as the major driving control. Our study region, the Vinchina Basin, is at present located in a transitional zone between flat and normal subduction [see Cahill and Isacks, 1992; Anderson et al., 2007]. We followed the Yáñez et al. [2001] historical reconstruction of the central Andes to estimate the subduction geometry below the Vinchina Basin during the Miocene and Pliocene. According to this work, the region would have been affected by normal subduction before 13 myr and more recently than 6 myr; in a transitional situation between flat and normal subduction between 13 and 11 myr as well as 8 and 6 myr; and underlain by flat subduction between 11 and 8 myr Heat flows were estimated considering conditions from Gutscher et al.'s [2000a] model at $~ 300 \pm$ $50 \mathrm{~km}$ from the trench (taking into account shortening). The specific heat flows used are: normal subduction stage, $30^{\circ} \mathrm{C} / \mathrm{km}\left(77.7 \mathrm{~mW} / \mathrm{m}^{2}\right)$; transitional subduction stage, $15^{\circ} \mathrm{C} / \mathrm{km}\left(38.85 \mathrm{~mW} / \mathrm{m}^{2}\right)$; flat subduction stage, $10^{\circ} \mathrm{C} / \mathrm{km}$ $\left(25.9 \mathrm{~mW} / \mathrm{m}^{2}\right)$. The thermal conductivity used to transform thermal gradients into heat flow values was $2.59 \mathrm{~W} /(\mathrm{mK})$ (from the software).

\section{Results}

\subsection{Petrography and Whole-Rock Mineralogy of Fine-Grained Rocks}

[18] The fined-grained rocks are mostly composed of millimeter-scale laminated, reddish-brown siltstones and claystones that alternate with fine-grained sandstones (sandstones to the sum of siltstones and claystones ratio

\footnotetext{
Figure 4. The distribution of mixed-layer clays (interstratified I/S) in the stratigraphic columns of the (a) Vinchina Basin at Sierra de Los Colorados and (b) Cordón de la Flecha. To the right of each column are shown decomposition of EG-XRD diagrams of each sample: blue curves represents measured diagrams, black curves are decomposition curves and red curves are theoretical diagrams obtained after decomposition. Note the clear decrease, but without disappearing, of R0 I/S from top to bottom of the succession. Magnetostratigraphic ages (*1, Re and Barredo [1993];*4, Reynolds et al. [1990]), zircon fission track ages in tuffaceous levels (*2, Tabbutt [1986]; *5, Reynolds et al. [1990]), and U-Pb detrital zircon age (*3, this work) obtained for the Sierra de los Colorados and Cordón de la Flecha section, are also shown.
} 
Table 1. Whole Rock Mineralogy and Clay Mineral Phases From Both Sections

\begin{tabular}{|c|c|c|c|c|c|c|c|c|c|c|c|c|c|c|c|c|c|c|}
\hline & \multirow{2}{*}{$\begin{array}{l}\text { Depth } \\
\text { (m) }\end{array}$} & \multirow[b]{2}{*}{ Sample } & \multicolumn{11}{|c|}{ Whole Rock Mineralogy } & \multicolumn{5}{|c|}{ Clay Fraction Mineralogy, $<2 \mu \mathrm{m}(\%)$} \\
\hline & & & Crs & $\mathrm{Sa}$ & Qtz & $\mathrm{Pl}$ & Kfs & Ms & Chl & Cal & Hul & Anl & Hem & Illite & I/S R3 & I/S R1 & I/S R0 & $\mathrm{Chl}$ \\
\hline \multicolumn{19}{|c|}{ Los Colorados } \\
\hline \multirow[t]{4}{*}{ Toro Negro Fm. } & 500 & RT100 (tuff) & $\mathrm{X}$ & $\mathrm{X}$ & & $\mathrm{X}$ & & $\mathrm{X}$ & & & & & $\mathrm{X}$ & & & & & \\
\hline & 500 & RT100 & & & $\mathrm{X}$ & $\mathrm{X}$ & $\mathrm{X}$ & $\mathrm{X}$ & & $\mathrm{X}$ & $?$ & & $\mathrm{X}$ & & & & & \\
\hline & 1300 & RT5 & & & $\mathrm{X}$ & $\mathrm{X}$ & $\mathrm{X}$ & $\mathrm{X}$ & $\mathrm{X}$ & $\mathrm{X}$ & $?$ & & $\mathrm{X}$ & 26 & 0 & 2 & 72 & $\mathrm{X}$ \\
\hline & 1900 & RT101 & & & & & & & & & & & & & & & & \\
\hline \multirow[t]{5}{*}{ Vinchina Fm. } & 4500 & RT4 & & & & & & & & & & & & 62 & 11 & 6 & 21 & $\mathrm{X}$ \\
\hline & 4750 & RT3 & & & $\mathrm{X}$ & $\mathrm{X}$ & $?$ & $\mathrm{X}$ & $\mathrm{X}$ & $\mathrm{X}$ & $\mathrm{X}$ & & $\mathrm{X}$ & 41 & 11 & 5 & 43 & $\mathrm{X}$ \\
\hline & 5900 & RT2 & & & $\mathrm{X}$ & $\mathrm{X}$ & ? & $\mathrm{X}$ & $\mathrm{X}$ & & & & $\mathrm{X}$ & 69 & 10 & 4 & 17 & $\mathrm{X}$ \\
\hline & 6900 & RT106 & & & $\mathrm{X}$ & $\mathrm{X}$ & ? & $\mathrm{X}$ & $\mathrm{X}$ & $\mathrm{X}$ & & $\mathrm{X}$ & $\mathrm{X}$ & & & & & \\
\hline & 7000 & RT1 & & & $\mathrm{X}$ & $\mathrm{X}$ & $\mathrm{X}$ & $\mathrm{X}$ & & & & $\mathrm{X}$ & & 42 & 23 & 5 & 30 & $\mathrm{X}$ \\
\hline \multicolumn{19}{|c|}{ La Flecha } \\
\hline Zapallar Fm. & 790 & RLT11 & & & $\mathrm{X}$ & $\mathrm{X}$ & $\mathrm{X}$ & $\mathrm{X}$ & $?$ & $\mathrm{X}$ & & & $\mathrm{X}$ & 12 & 0 & 0 & 88 & $\mathrm{X}$ \\
\hline \multirow[t]{3}{*}{ Vinchina Fm. } & 2780 & RLT8 & & & $\mathrm{X}$ & $\mathrm{X}$ & $\mathrm{X}$ & $\mathrm{X}$ & $\mathrm{X}$ & $\mathrm{X}$ & & & $?$ & 62 & 0 & 2 & 36 & $\mathrm{X}$ \\
\hline & 3340 & RLT7 & & & $\mathrm{X}$ & $\mathrm{X}$ & $\mathrm{X}$ & $\mathrm{X}$ & $\mathrm{X}$ & $\mathrm{X}$ & $\mathrm{X}$ & $\mathrm{X}$ & $\mathrm{X}$ & 38 & 15 & 7 & 40 & $\mathrm{X}$ \\
\hline & 4220 & RLT6 & & & $X$ & $X$ & $\mathrm{X}$ & $\mathrm{X}$ & $\mathrm{X}$ & & & $\mathrm{X}$ & $\mathrm{X}$ & 52 & 9 & 7 & 32 & $\mathrm{X}$ \\
\hline
\end{tabular}

ranges throughout section between $2: 1$ and 5:1). The siltstones are composed of quartz, plagioclase, potassium feldspar, lithic fragments, iron-rich opaque grains (hematite) and detrital muscovite, biotite and chlorite. Siltstones and fine-grained sandstones show iron-oxide coatings predating compaction. These coatings are responsible for the red color of the units and are recorded along the entire column. Calcitic cement is abundant at the upper levels and disappears at $\sim 5.9 \mathrm{~km}$ below the surface (b.s.) in Sierra de los Colorados section and $\sim 3.3 \mathrm{~km}$ (b.s.) in Cordón de la Flecha section. The weakly indurated claystones are relatively homogeneous through all the sequence and contain fine grained white mica, fine-grained quartz (with iron-oxide coatings), detrital white mica $(0.003-0.05 \mathrm{~mm})$ and plagioclase, with subordinated chlorite and k-feldspar grains. Some zeolite phases such as analcime and heulandite were also identified through XRD (Table 1) from $\sim 4.7 \mathrm{~km}$ (b.s.) in the Sierra de los Colorados section and from $\sim 3.3 \mathrm{~km}$ (b.s.) in Cordón de la Flecha section, although textural relations with the other cements could not be established through petrography. Expandable clay minerals are not abundant in XRD bulk rock analysis.

[19] Although samples from the Toro Negro and Vinchina formations have a similar composition, suggesting similar detrital contributions, XRD bulk rock analysis shows that shallower levels contain higher amounts of k-feldspar and minor amounts of cristobalite (derived from tuff levels), whereas deeper levels in the Vinchina Formation contain analcime and heulandite (Table 1). These differences are probably related to postdepositional-burial diagenetic mineralogical changes. Although the origin of zeolites could be related with alteration of the abundant volcanic material present within the units, more textural and mineralogical analyses need to be made to elucidate their origin as well as the textural relations with the neoformed clay minerals.

\subsection{Clay Mineralogy $(<2 \mu \mathrm{m})$}

[20] The dominant neoformed clay mineral phases identified through XRD are smectite, interstratified I/S, illitemica in variable proportions and lesser amounts of chlorite (Table 1 and Figure 4). The simple and traditional characterization of I/S, using the positions of $001 / 002$ and $002 / 003$ reflections to estimate I\% [Moore and Reynolds, 1997], is difficult to apply in these samples given the mixture of the illite-mica phase and the overlapping reflections. Moreover, comparisons between AD and EG XRD suggest the presence of multiple expandable I/S phases with different $\mathrm{S} \%$ in each sample. Detailed decomposition analyses of both XRD diagrams show the coexistence of interstratified I/S with R0, R1 and R3 orderings (Figure 4). R0 presents spacing that ranges from 13.13 to $15.54 \AA$ in $\mathrm{AD}$ diagrams and 16.08 to $17 \AA$ in $\mathrm{EG}$ diagrams. R1 and R3 show a lower spacing as well as a minor difference between $\mathrm{AD}$ and $\mathrm{EG}$ diagrams, ranging from 11.32 to $12.60 \AA$ to $11.98-13.71 \AA$ and $10.47-$ $11.12 \AA$ to $10.59-11.20 \AA$, respectively. This coexistence is reinforced by results from SEM (Figure 5) and TEM analyses carried out in two of the samples (RT5, RT1; Figure 6 and auxiliary material).

[21] The clay mineral assemblage of the shallowest sample (RT5) along the Sierra de los Colorados (Figure 4; 1.25 km depth, uppermost section in the Toro Negro Formation) is dominated by R0 ( 70\%), R1 and illite-mica phases, with absence of R3 ordering. The I/S structural formula, calculated from AEM analyses on the basis of 11 oxygens, shows compositional variations with $\mathrm{Si}$ contents ranging from 3.41 to 3.94 a.p.f.u., layer charges between -0.25 and -0.74 and $\mathrm{K}, \mathrm{Na}$ and $\mathrm{Ca}$ as interlayer cations. The appearance of R3 within the Vinchina Formation, absent in the above Toro Negro Formation, takes place at $\sim 5 \mathrm{Km}$ depth (e.g., $5 \mathrm{~km}$ from the uppermost part of the preserved basin) and, likewise, R1 and illite show an increase toward the base of the unit. Although R0 clearly decreases to the deeper levels, significant proportions $(\sim 30 \%)$ are still present in the lowermost analyzed sample (RT1, $\sim 7 \mathrm{Km}$ depth). The R0 persistence to $7 \mathrm{~km}$ depth is confirmed by the AEM that indicates phases with $\mathrm{Si}$ contents of 3.91 a.p.f.u. and layer charges of -0.28 (Figure 6).

[22] In the section at Cordón de la Flecha (Figure 2a), the shallowest sample RLT11 (in the Zapallar Formation) are dominated by R0 ( $88 \%)$, with subordinated illite-mica and chlorite. R1 phases are recorded from $\sim 2.8 \mathrm{~km}$ downward, within the Vinchina Formation (RLT8, RLT7 and RLT6), and R3 ordering was identified only in the two deepest levels below $\sim 3.4 \mathrm{~km}$ (RLT7 and RLT6). As in the Sierra de 

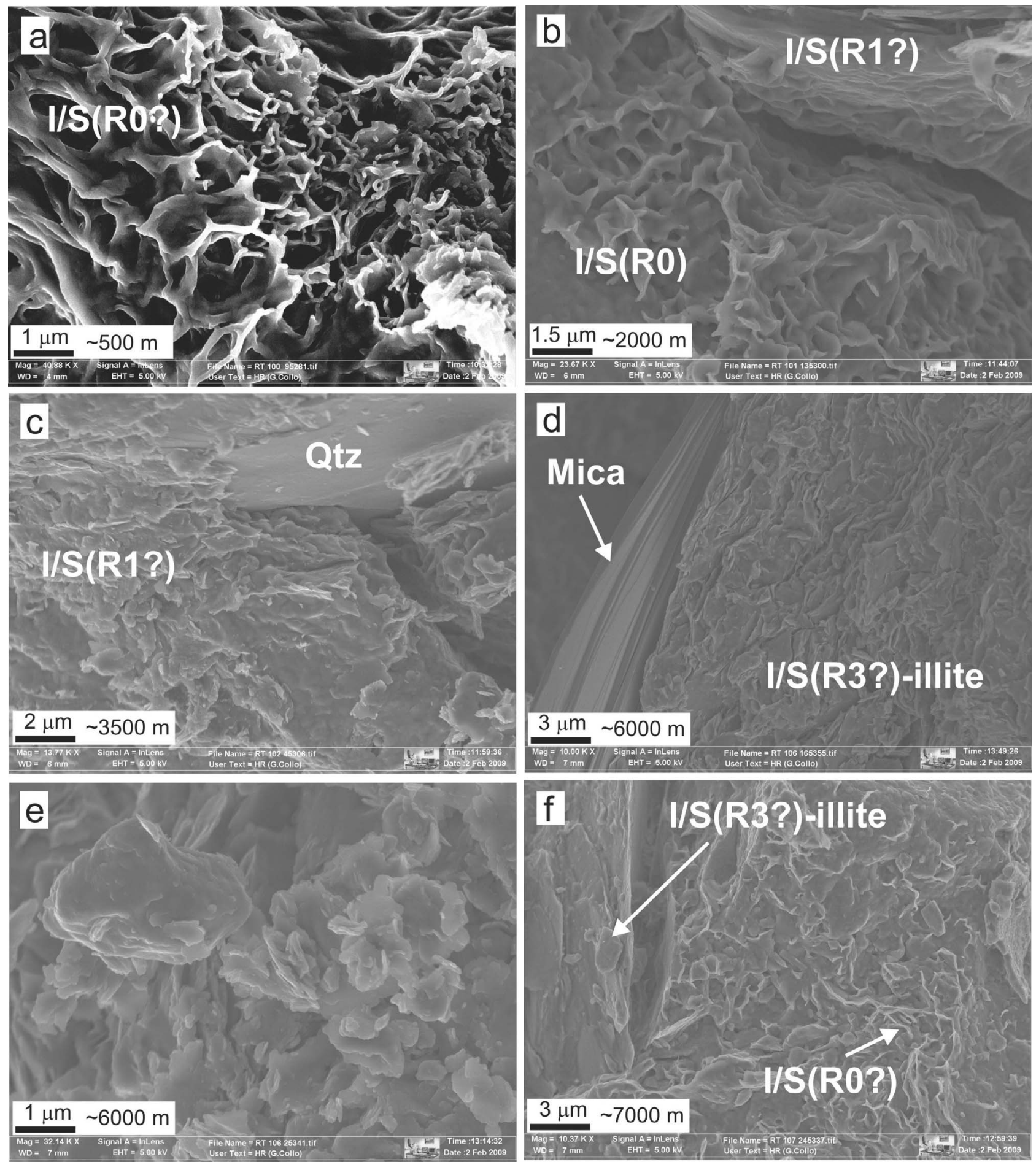

Figure 5. Scanning electron micrographs show differing textures of I/S and Illite in the different levels at Sierra de los Colorados. (a) Detail of honeycomb R0 I/S interstratified at $500 \mathrm{~m}$, (b) honeycomb R0 I/S interstratified at $2000 \mathrm{~m}$, (c) I/S flakes developed over quartz overgrowths at $\sim 3500 \mathrm{~m}$; (d) detrital mica plate and contrasting I/S and illite neoformed flakes at $\sim 6000 \mathrm{~m}$, (e) detail of neoformed phases from the previous photomicrograph; and (f) I/S and illite at $\sim 7000 \mathrm{~m}$. Note the persistence of honeycomb texture typical of R0 interstratified.

los Colorados, $\mathrm{R} 0$ ordering is still recorded at around $4.6 \mathrm{~km}$ depth (RLT6).

[23] The increase of R1 ordering and illite with depth, the appearance of R3 ordering at $\sim 3-3.5 \mathrm{~km}$ and the persistence of R0 ordering at the base of the Vinchina Formation, are characteristics of both localities. They also show an increase of illite downward in the section, associated with a displacement of the 001 reflection toward the higher degrees 

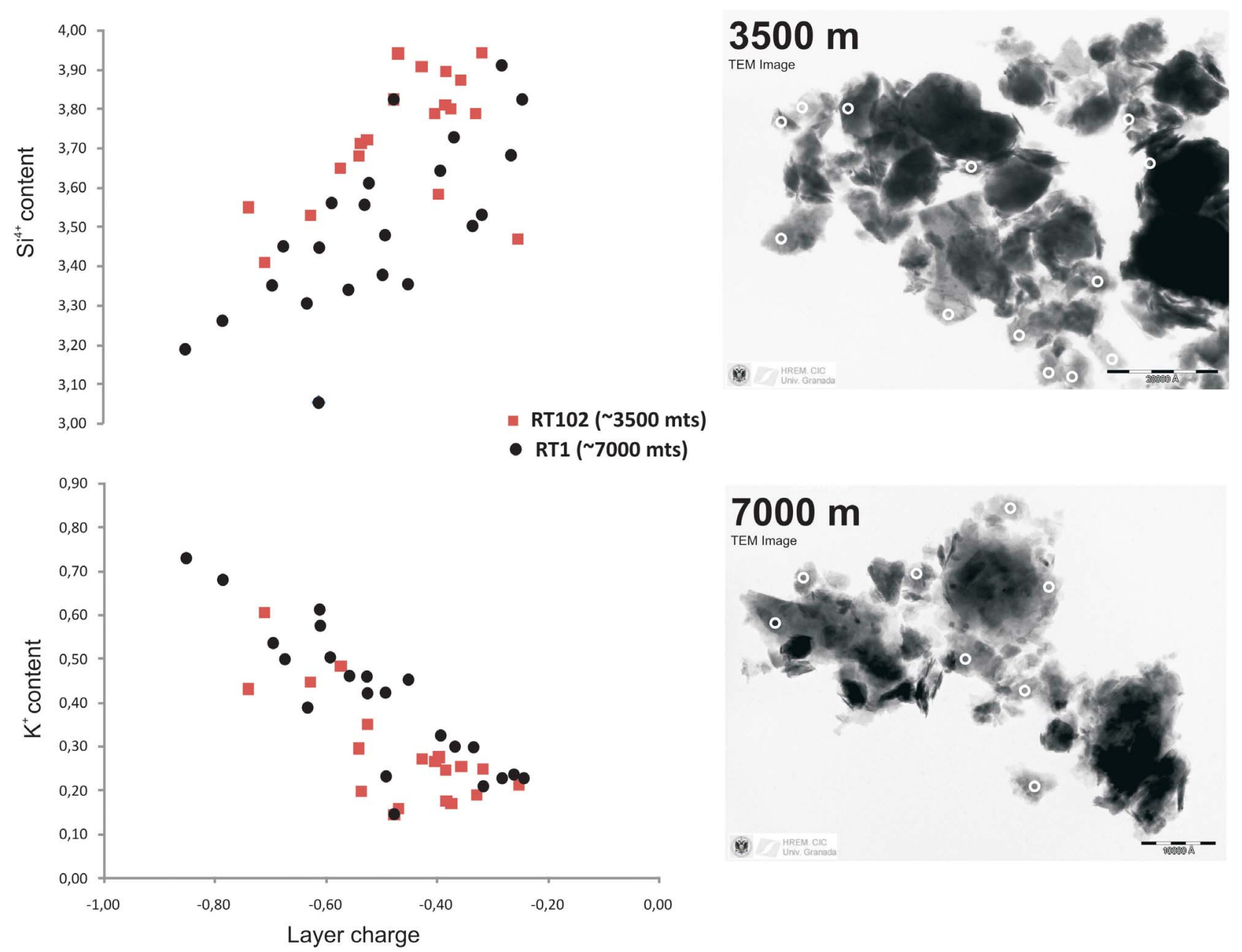

Figure 6. Diagrams showing wide dispersion in the chemical compositions of the I/S and illite phases even in the sample at $\sim 7000 \mathrm{~m}$ depth. Some of the measured spots are shown with circles in the TEM images to the right.

and a decrease in the peak width at half height. It is important to note that small proportions of illite-mica exist at the shallowest levels of both sections, likely reflecting a detrital contribution. Chlorite appears in similar proportions throughout all the sequence.

\subsection{Thermal Modeling}

[24] Several thermal models were carried out with PetroMod in order to test the thermal conditions of the basin during de Neogene. The thermal evolution of the Vinchina Basin at Sierra de los Colorados and Cordón de la Flecha were reconstructed under four different conditions (see Figures 7 and 8 for further explanations): (1) considering the Neogene subduction dynamic proposed by Yáñez et al. [2001] and the thermal parameters calculated by Gutscher et al. [2000a] for different subduction scenarios, (2) considering a decline in the geothermal gradient taking into account that the isotherms of Gutscher et al. [2000a] should be placed lower, (3) considering the study region behaved as a transitional subduction scenario between 8 and $3.4 \mathrm{Myr}$, and (4) combining conditions 2 and 3.
[25] As shown in the Figures 7 and 8, the maximum calculated temperatures vary between 90 and $225^{\circ} \mathrm{C}$ in the Sierra de los Colorados and between 105 and $150^{\circ} \mathrm{C}$ in the Cordón de la Flecha section. The maximum temperatures would have been reached at the base of the entire sedimentary section at $\sim 3.4 \mathrm{Ma}$ in the Sierra de los Colorados section and between 3 and $3.6 \mathrm{~km}$ depth at $\sim 12-13 \mathrm{Ma}$ in Cordón de la Flecha section.

[26] For the Cordón de la Flecha, the four models were also run considering continuity of sedimentation until $3.4 \mathrm{Ma}$ and with a sedimentation rate of $\sim 540 \mathrm{~m} / \mathrm{myr}$ (rate between $\sim 12.2$ and $\sim 9 \mathrm{Ma}$ [Reynolds et al., 1990]; see auxiliary material). In these models the maximum burial temperatures would have been between 120 and $300^{\circ} \mathrm{C}$ at $8 \mathrm{~km}$ depth.

\subsection{Detrital U-Pb Ages}

[27] The analyzed volcanogenic sample from the lowermost section ( 6900 m depth) of the Vinchina Fm at Sierra de los Colorados (Figures $2 \mathrm{a}$ and 9 and auxiliary material) comes from a very thick $(1.5 \mathrm{~m})$ whitish to grayish laminated tuffaceous sandy bed, composed of lithic and volcaniclastic 

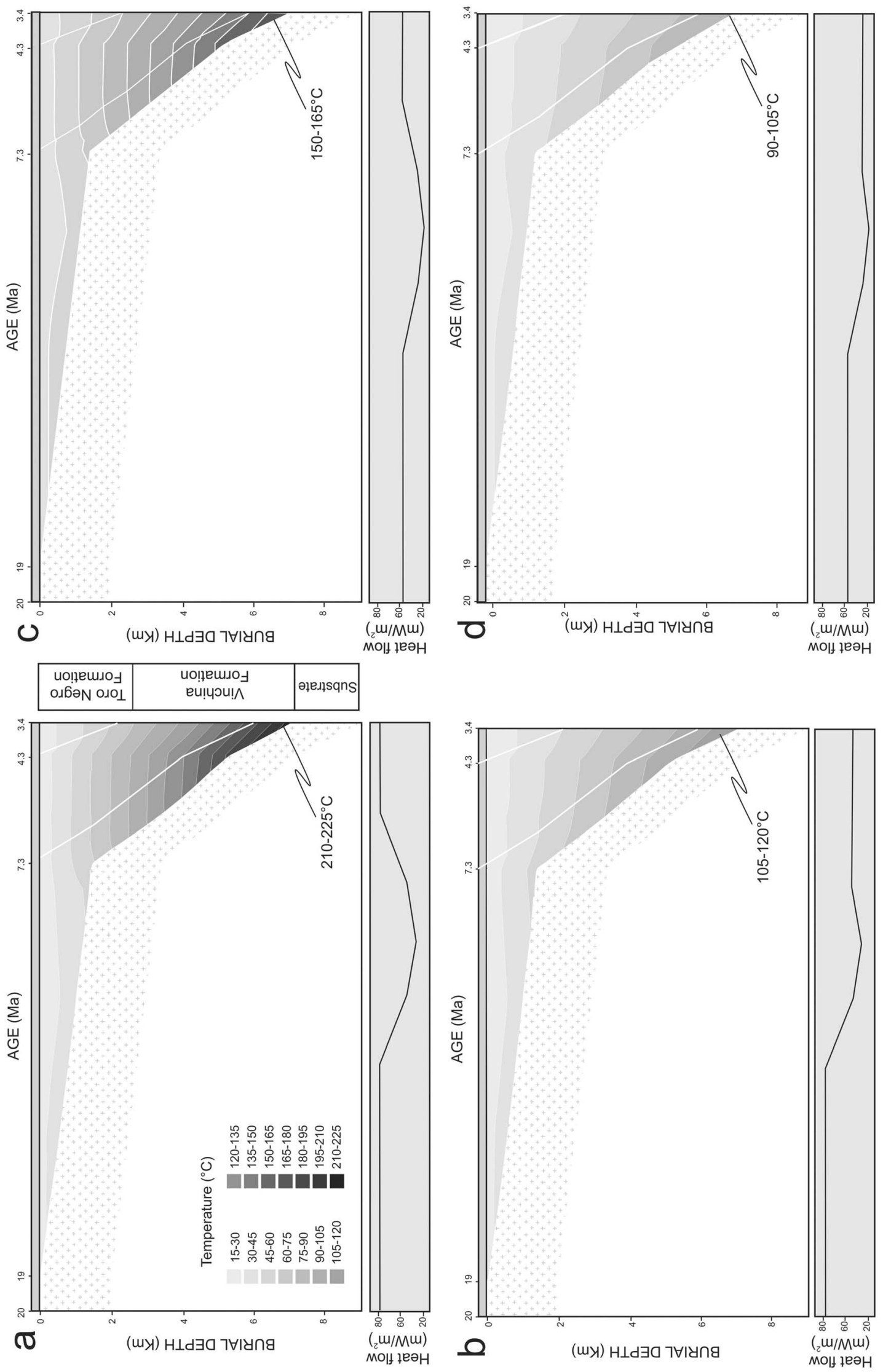

包 
components and interpreted to be a reworked tuff. Tephra components are slightly recrystallized and silicified including variously cuspate to planar glass shards and conchoidal fragmented quartz, plagioclase, k-feldspar, amphibole and micas (mainly euhedral biotites). Accompanying rounded quartz and feldspars, biotite and muscovite flakes are also common as well as a few accessory transparent heavy minerals including prismatic zircon grains. The lithics are volcanic, metamorphic and equigranular (microgranites). Locally it is possible to recognize a poorly developed groundmass of fine-grained microcrystalline siliceous material (derived from glass devitrification) and patchy calcitic cement. In outcrop, this horizon shows cross and trough lamination, locally with deep incisions, indicating turbulent flow. Sedimentological features and composition suggests some reworking for this well-known thick tuff level that was analyzed by Tabbutt [1986]. Whole rock XRD analysis shows that the k-feldspar is mainly of sanidine type, and mordenite appears as the main zeolitic phase presumably as neoformed cement.

[28] U-Pb ages on detrital zircons indicate a wide age range, from Proterozoic to Cenozoic ( 1912.6 Ma to $\sim 19.1 \mathrm{Ma}, \mathrm{n}=$ 75; Figure 9 and auxiliary material). The younger four zircons tightly average at ca. $19 \mathrm{Ma}$ and show a mean age of $19.4 \pm$ $0.7 \mathrm{Ma}$ (MSWD $=0.53,2 \sigma$ errors). The density plot shows six distinct major populations at $19 \mathrm{Ma}, 288 \mathrm{Ma}, 463 \mathrm{Ma}$, $504 \mathrm{Ma}, 547 \mathrm{Ma}$ and $1141 \mathrm{Ma}$. Minor peaks are recorded at $1464 \mathrm{Ma}$ and $1842 \mathrm{Ma}$. In cathodoluminescence images the Proterozoic-Paleozoic zircons are rounded to subrounded, whereas Tertiary zircons are prismatic and zoned and are likely cogenetic with volcanism. This allows interpreting a maximum sedimentation age of ca. 19 Ma for the primary volcanic components in the tuffaceous bed. The rest of the detrital grains, as inferred from independent sedimentological features, indicate stream-related recycling and a mixed provenance from local basement and early and late Paleozoic plutons and sedimentary cover.

\section{Discussion}

\subsection{Detrital U-Pb Ages: Deposition and Provenance}

[29] The U-Pb ages not only assist to constrain the depositional age but also help to determine the origin and provenance of the tuffaceous level exposed at the base of the Vinchina Formation. Although the youngest detrital age in a sedimentary rock is, by definition, a maximum age, it is noteworthy that there are no grains younger than 19 Ma. Given that volcanism was very active from Early Miocene to Pliocene time in this region, it is reasonable to interpret that the ca. $19 \mathrm{Ma}$ (Early Miocene) peak might be close to a depositional age. This suggests that the base of the Vinchina Formation at Sierra de los Colorados was deposited at ca. $19 \mathrm{Ma}$, instead of the 14.5 Ma proposed by Re and Barredo [1993], and is consistent with the magnetostratigraphic study on the correlative section of Cordón de la Flecha carried out by Reynolds et al. [1990] that constrained the base of the Vinchina Formation at $\sim 18 \mathrm{Ma}$.

[30] The zircon age results also have implications regarding the source area of the foreland basin strata. The lack of Mesozoic and Early Tertiary detrital zircons suggests that Choiyoi (Triassic) and the earliest Andean (Paleogene) records exposed today along the main cordillera [Astini et al., 2009] were not sources for the lowermost Vinchina Fm. Although paleocurrent studies show general paleoslopes to the east [Ramos, 1970; Tripaldi et al., 2001], given the abundance of Neoproterozoic and early and late Paleozoic detrital ages we cannot discard the possibility of an early supply from adjacent provinces like the Precordillera, Sierras Pampeanas or Puna, where some of these ages are also present. Alternatively, because regional paleocurrents are toward the east from the beginning of the sedimentation, detrital ages may demonstrate that the Triassic to Paleogene interval was not unroofed along the High Cordillera, although this contradicts thermochronological analysis in Chile [e.g., Nalpas et al., 2005] that show three major cooling ages (Mid-Cretaceous to Paleogene in the coast, Eocene in the Central Valley region and Oligo-Miocene close to the Argentina-Chile border). According to our results, the erosion and transport of Mesozoic to Paleogene rocks had to occur younger than $19 \mathrm{Ma}$, following deposition of the analyzed tuffaceous sandstone, and likely during the deposition of the Mio-Pliocene coarse conglomerates of the overlying Toro Negro Fm. Another alternative is a source area located to the north, in the southern Puna plateau, as previously suggested by Coughlin [2002] and Carrapa et al. [2005] based on detrital apatite fission track analysis.

\begin{abstract}
Figure 7. Thermal modeling for the Vinchina Basin at Sierra de los Colorados section using PetroMod 1D Express software. Given the Vinchina basin is nonmarine, PWD is zero and SW1 is $\sim 20^{\circ} \mathrm{C}$. Heat flows estimated considering conditions at $\sim 300 \pm 50 \mathrm{~km}$ from the trench (taking into account shortening): normal subduction stage, $30^{\circ} \mathrm{C} / \mathrm{km}\left(77.7 \mathrm{~mW} / \mathrm{m}^{2}\right)$; transitional subduction stage, $15^{\circ} \mathrm{C} / \mathrm{km}\left(38.85 \mathrm{~mW} / \mathrm{m}^{2}\right)$; flat subduction stage, $10^{\circ} \mathrm{C} / \mathrm{km}\left(25.9 \mathrm{~mW} / \mathrm{m}^{2}\right)$ [from Gutscher et al., 2000a]. Thermal conductivity used to transform thermal gradients in heat flow values: 2.59 (W/mK) (from the software). Modeling includes blanketing effects related to sedimentation and exhumation rates. Sedimentation stages for the Sierra de los Colorados: 19-7.30 myr, $1100 \mathrm{~m} ; 7.30-4.30 \mathrm{myr}, 3650 \mathrm{~m}$; and 4.30-3.40 myr, $2250 \mathrm{~m}$. (a) Considering the recovery to normal subduction geometry. Time intervals from Yáñez et al. [2001]: normal subduction stage, before 13 myr; transitional subduction stage, 13-11 myr; flat subduction stage, 11-8 myr; transitional subduction stage, 8-6 myr; and normal subduction stage, between 6 and 3.4 myr. (b) Considering a decline in the thermal gradient ( $25 \%)$ taking into account that the isotherms of Gutscher et al. [2000a] should be placed lower: normal subduction stage, $22.5^{\circ} \mathrm{C} / \mathrm{km}\left(58.275 \mathrm{~mW} / \mathrm{m}^{2}\right)$; transitional subduction stage, $11.25^{\circ} \mathrm{C} / \mathrm{km}\left(29.1375 \mathrm{~mW} / \mathrm{m}^{2}\right)$; and flat subduction stage, $7.5^{\circ} \mathrm{C} / \mathrm{km}\left(19.425 \mathrm{~mW} / \mathrm{m}^{2}\right)$. (c) Considering an incomplete recovery of normal subduction geometry. Time intervals are normal subduction stage, after 15 myr; transitional subduction stage, 15-11 myr; flat subduction stage, 11-8 myr; and transitional subduction stage, between 8 and 3.4 myr. (d) Considering a decline in the thermal gradient proposed by Gutscher et al. [2000a] together with an incomplete recovery of normal subduction geometry.
\end{abstract}



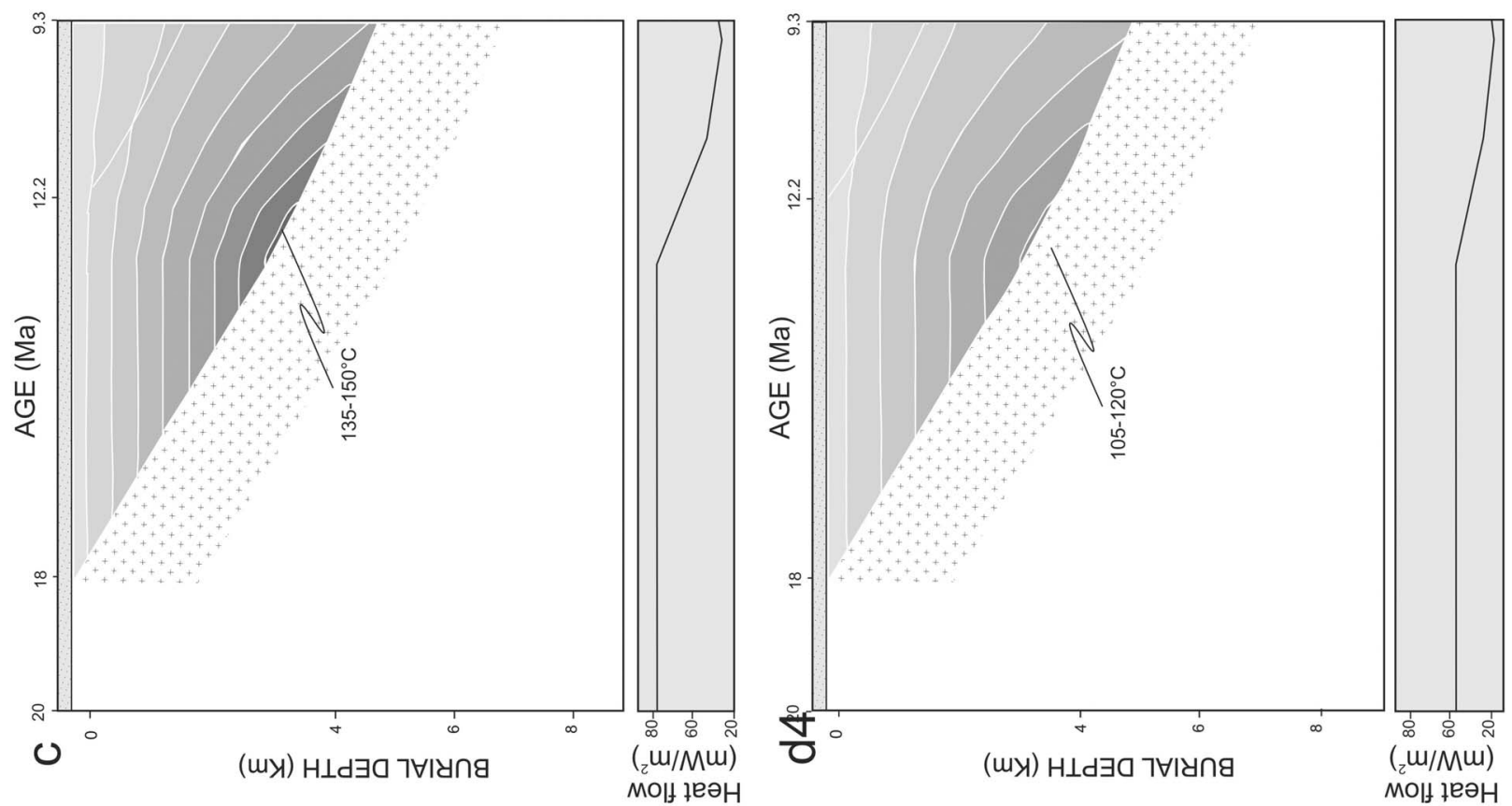

ฮี

$\sum_{0}$

战

ขี้ สิ

爻

$\exists$

응

은

o.

吾

을

造

긍

II
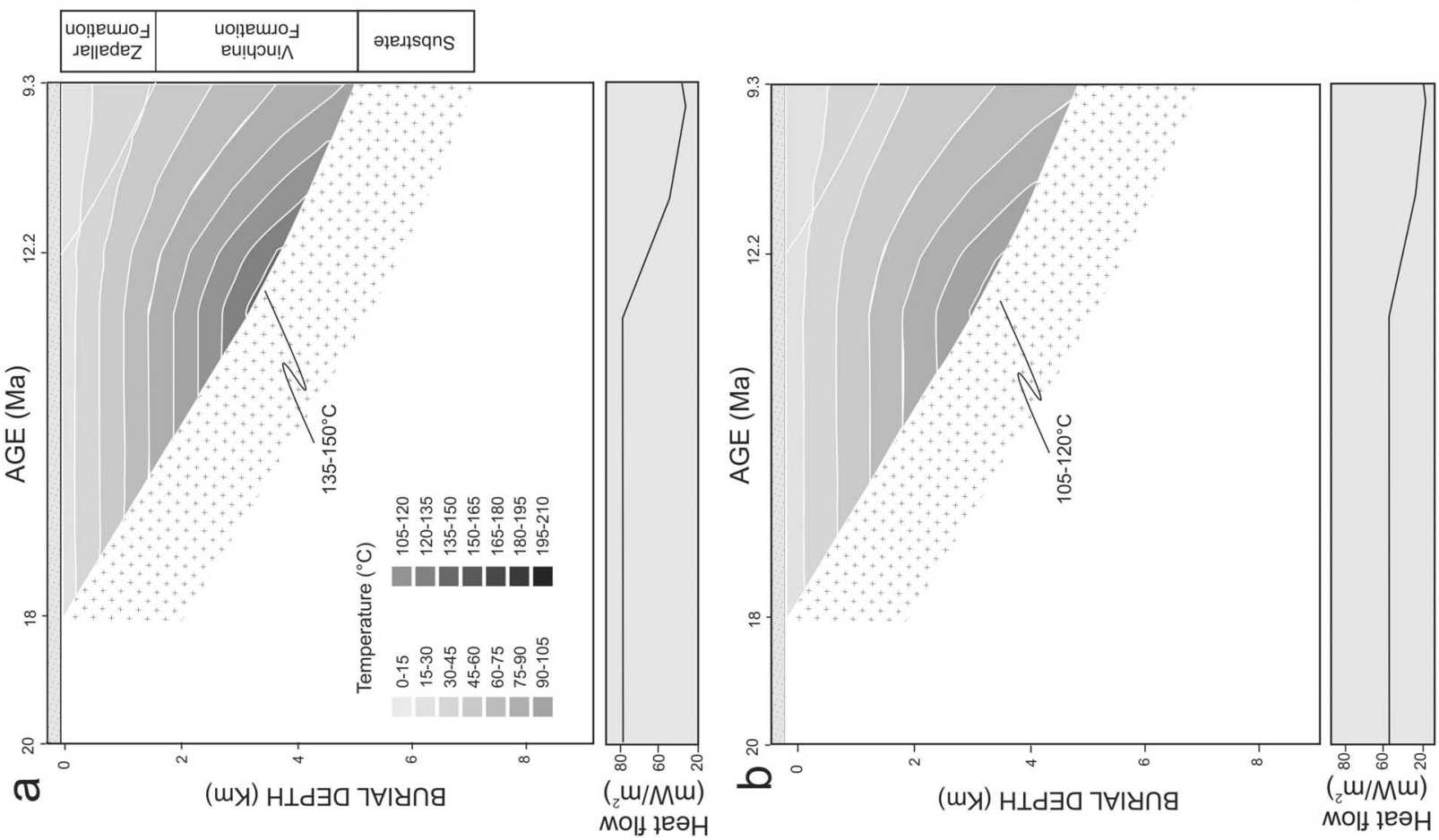

항

흥 ?

ํํํ

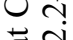

$\Xi$ 금

ข

코

층 응

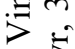

\& હ

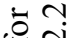

.

늠 


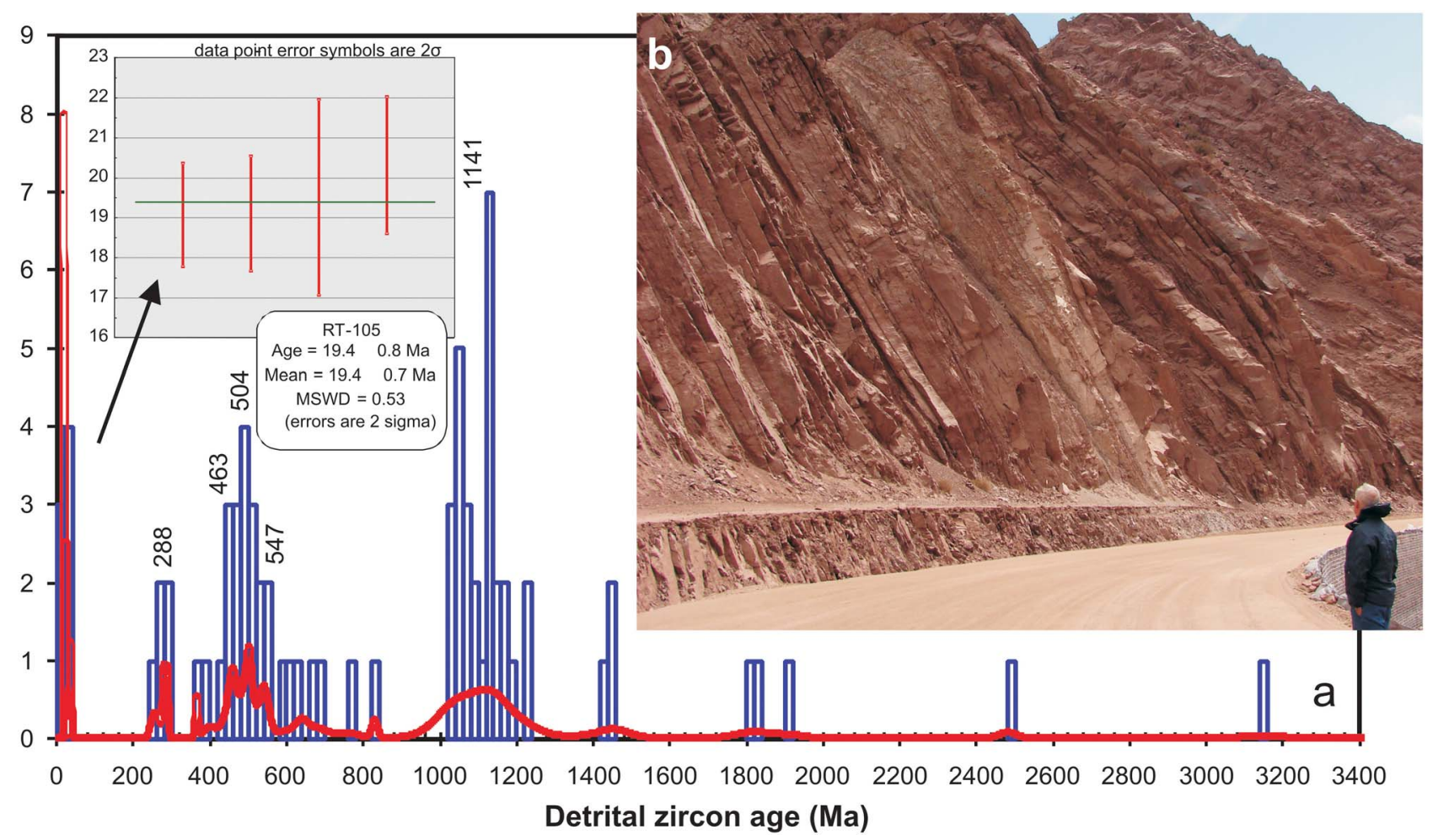

Figure 9. (a) U-Pb detrital zircon ages of the lowermost volcanogenic bed exposed in the Vinchina Formation, Sierra de Los Colorados. The inset at the left-top corner is depicting the age dispersion of the youngest zircons that provided the minimum age for the units in $\sim 19 \mathrm{Ma}$. (b) Dated tuff layer within the Vinchina Formation.

\subsection{Postdepositional Processes}

\subsubsection{Progress of Illitization and Estimate of Ancient Thermal Gradients}

[31] The distribution of I/S interstratified phases through the succession (Figure 4) shows a progressive smectiteillitization process $(\mathrm{R} 0 \rightarrow \mathrm{R} 1 \rightarrow \mathrm{R} 3 \rightarrow \mathrm{I})$ directly related to the sedimentary burial history of the late Tertiary succession. Although part of the smectite and I/S in the $<2 \mu \mathrm{m}$ fraction from the shallower levels may have been derived from the source area (as well as illite-mica and chlorite), the increment in the I/S ordering and illite content from the top to the bottom of the section and the strong correlation between the degree of illitization and the stratigraphic position of the rocks shows that, at least in the deepest levels, I/S phases (including the R0) are neoformed and transformed grains. These are related consequently to diagenetic transformations. AEM data (Figure 6) also demonstrate a coexistence of $\mathrm{R} 0, \mathrm{R} 1, \mathrm{R} 3$ and Illite phases in the deepest sample, eliminating the possibility that the expandable phases as result from rock alteration following exhumation, which generally generates contrasted endmembers populations. The distribution of $\mathrm{I} / \mathrm{S}$ is compatible with the typical trajectory found in modern and ancient clastic basins affected by "incipient burial metamorphism" [e.g., Velde and Vasseur, 1992, and references therein], and allow avoiding stratigraphic duplication or tectonic thickening in the succession.

[32] The presence of $\mathrm{R} 0$ randomly mixed-layered $\mathrm{I} / \mathrm{S}$ with $>50 \%$ content of smectite at $\sim 7 \mathrm{~km}$ depth in the Sierra de los
Colorados and at $\sim 4.8 \mathrm{~km}$ depth in the Cordón de la Flecha, suggests that the base of the section in the Vinchina basin did not exceed the diagenetic field [cf. Frey and Robinson, 1999]. Consequently we can confidently propose that the Vinchina Basin behaved as an immature and cold basin. The persistence of minor amounts of potassium feldspar even in the deepest samples ( $\sim 7 \mathrm{~km}$ depth) implies that the delay in the smectite to illite transformation was not related to the low concentrations of potassium bearing minerals, as suggested for the clay mineral evolution in sequences as the Gulf Coast or Central Basin of Poland [Srodon and Eberl, 1984].

[33] Because R0 becomes unstable over temperatures of $\sim 120^{\circ} \mathrm{C}$ in siliciclastic sequences [Jennings and Thompson, 1986; Sucha et al., 1993; Uysal et al., 2000], the maximum average paleogeothermal gradient reached by the Vinchina basin fill at depths of $\sim 7 \mathrm{~km}$, and considering surface temperatures of $\sim 20^{\circ} \mathrm{C}$, would be in the order of $\sim 15^{\circ} \mathrm{C} / \mathrm{Km}$ (Figure 10). This value is consistent with thermochronological studies that suggest the sequence would not have exceeded the AFT partial annealing zone temperatures of $\sim 120^{\circ} \mathrm{C}$ at these depths in the Sierra de los Colorados section [Coughlin, 2002]. No Tertiary AFT ages were recorded, at least for this segment, as expected for a conservative thermal gradient at $7 \mathrm{~km}$ depth. It is noteworthy that our temperature values are also consistent with heat flow studies in the modern Andean foreland [see Muñoz, 2005; Hamza et al., 2005] that reported gradients as low as $17^{\circ} \mathrm{C} / \mathrm{km}$ in the Chaco Plains of Paraguay and Brazil. 


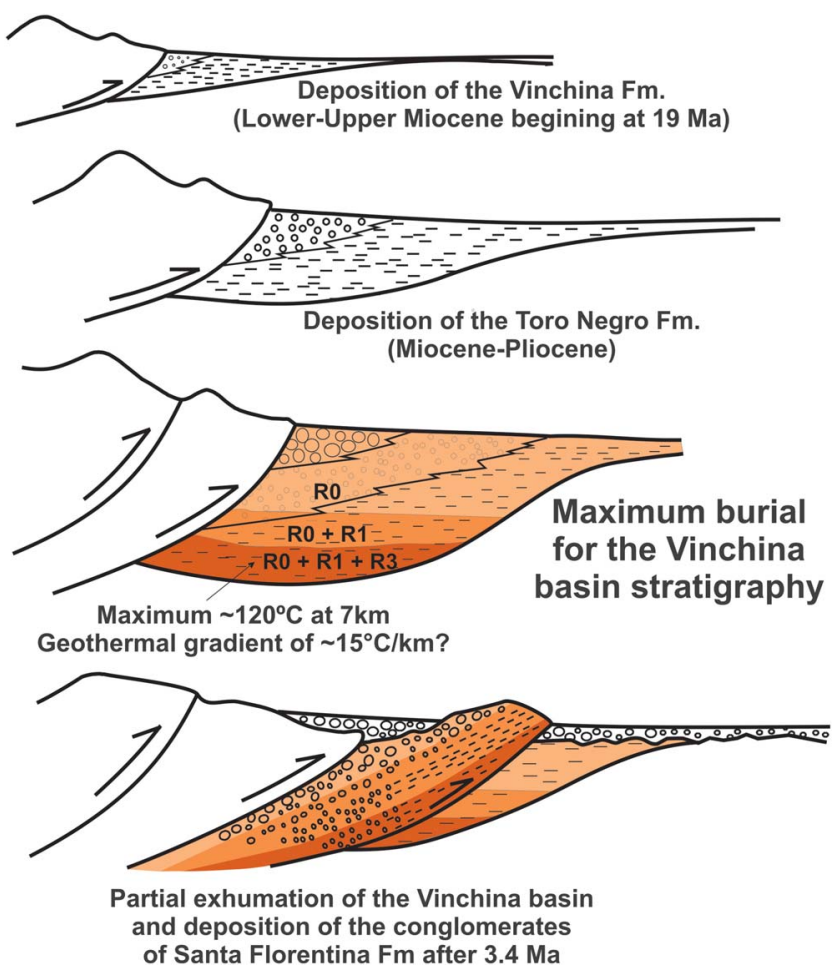

Figure 10. Schematic burial-exhumation history proposed for the Vinchina Basin fill.

\subsubsection{Implication of the Thermal Estimates}

[34] Estimated depositional age for the basal section of the Vinchina Formation, both geochronologically and magnetostratigraphically, together with ages of the uppermost Toro Negro Formation [Tabbutt, 1986], confirms that sedimentation of the Vinchina Basin at Sierra de los Colorados occurred between $\sim 19$ and 3.4 Ma (Early Miocene-Pliocene). In turn, geochronology and magnetostratigraphy at Cordón de la Flecha section [Reynolds et al., 1990] indicate that sedimentation of Vinchina and Zapallar Formations occurred between $\sim 18-9.3 \mathrm{Ma}$ (Early to Late Miocene).

[35] The established maximum average geothermal gradient for the Vinchina Basin $\left(\sim 15^{\circ} \mathrm{C} / \mathrm{km}\right)$, together with thermal conductivities between 2.2 and $2.8 \mathrm{~W} /(\mathrm{mK})$ [Turcotte and Schubert, 2002; Hamza et al., 2005], give average values between 33 and $42 \mathrm{~mW} \mathrm{~m}^{-2}$ for the Early Miocene-Pliocene Vinchina Basin. This agrees with heat flow studies along modern flat slab segments that show values between 20 and $70 \mathrm{~mW} \mathrm{~m}{ }^{-2}$ (e.g., Peru flat slab segment [Henry and Pollack, 1988; Gutscher, 2002; Muñoz, 2005; Hamza et al., 2005]) and with temperature information recorded in five deep oil-industry boreholes $(>4000 \mathrm{~m}$ depth) located further south along the Bermejo Valley, and above the flat-slab segment (e.g., $29^{\circ}-34^{\circ}$ SL [Cahill and Isacks, 1992; Pardo et al., 2002; Anderson et al., 2007, Collo et al., 2010]). The corrected temperatures, following the American Association of Petroleum Geologists [1976] recommendations, give geothermal gradients of $16-17^{\circ} \mathrm{C} / \mathrm{km}$. In steep slab segments of the Central Andean region of northern Chile and southern Bolivia, high heat flow values $\left(\sim 50\right.$ to $\left.120 \mathrm{~mW} \mathrm{~m}^{-2}\right)$ are recorded [Henry and Pollack, 1988; Gutscher, 2002; Hamza et al., 2005], as well as in the Neuquén Basin with values generally over $\sim 46 \mathrm{~mW} \mathrm{~m}^{-2}$, and an average of $\sim 163 \mathrm{~mW} \mathrm{~m}^{-2}$ [Hamza et al., 2005].

[36] Although low heat flows might be the main cause of the retarded progression of the I/S ordering and of the persistence of R0 even at $7 \mathrm{~km}$ depth within the Vinchina Basin, possible alternative explanations could be (1) a blanketing effect [cf. Husson and Moretti, 2002], (2) a short "residence time" of the complete succession at maximum burial conditions, (3) a lateral migration of the depocenter associated with strong syndepositional deformation, this might have created the false impression that the Vinchina Formation was deeply buried, when instead the successively younger horizons might have offlapped to the west such that the older units were never deeply buried, and/or (4) groundwater circulation, a phenomenon that could prevent the attainment of a steady state geotherm. Kinetic reaction modeling [Eberl and Hower, 1976; Cuadros and Linares, 1996; Berger et al., 1997] suggests that a full smectite to illite transformation at $\sim 120^{\circ} \mathrm{C}$ takes $\sim 10^{4} \mathrm{yr}$. This would allow discarding the second alternative. Moreover, the lack of growth unconformities and the uninterrupted sedimentation within the Vinchina and Toro Negro/Zapallar formations (encompassed in the Neogene Vinchina Basin) drives us to reject the third alternative of depocenter shifting. Analysis of thermal control related to groundwater circulation carried out in foreland basins suggests that rocks at depth can be cooled below the recharge area, but with only a local development of high-amplitude thermal anomalies (a temperature decrease of 10 to $15^{\circ} \mathrm{C}$ at $3 \mathrm{~km}$ depth) [cf. Husson and Moretti, 2002]. Furthermore, the local incidence of fluid circulation is difficult to model.

[37] The blanketing effect (first alternative [Lucazeau and Le Douaran, 1985; Deming, 1994]) is produced by rapid sedimentary accumulation and causes the reduction of the steady state thermal flux. High sedimentation rates $(\sim 1000 \mathrm{~m} / \mathrm{Ma})$, accompanied by rapid subsidence, induces cooling and could disturb the thermal field reducing the heat flow by $10-20 \%$, taking more than 30 myr to restore the normal flux [Husson and Moretti, 2002]. In the Pliocene-Pleistocene Coastal Range basin of eastern Taiwan, for example, high percentages of smectite at $6 \mathrm{~km}$ depth (up to $65 \%$ in the I/S) were interpreted as a combination of high sedimentation rates ( $>5 \mathrm{~km} / \mathrm{myr}$ ), low paleogeothermal gradient $\left(14^{\circ} \mathrm{C} / \mathrm{km}\right)$ and kinetic limitations related to short duration of the maximum burial (about $100^{\circ} \mathrm{C}$ for less than 1 myr [Dorsey et al., 1988]). Three major depositional episodes can be inferred for the Vinchina Basin in the Sierra de los Colorados from available geochronological data: from 19 to $7.3 \mathrm{Ma}$ with a rate $\sim 95 \mathrm{~m} / \mathrm{myr}$ (considering the new age at the base of the unit), from 7.3 to $4.3 \mathrm{Ma}$ with a rate of $\sim 1216 \mathrm{~m} / \mathrm{myr}$, and between 4.3 and $3.4 \mathrm{Ma}$ with a rate of $\sim 2500 \mathrm{~m} / \mathrm{myr}$. In turn, in the Cordón de la Flecha section, the rate of accumulation varies from a minimum of $\sim 300 \mathrm{~m} / \mathrm{myr}$ at the base, to a maximum of $1000 \mathrm{~m} / \mathrm{myr}$ in the middle, and then $400 \mathrm{~m} / \mathrm{myr}$ at the top [Reynolds et al., 1990]. These values allow estimating a heat flow reduction of around 15-20\% [cf. Husson and Moretti, 2002] by blanketing disturbances. The available geochronological analyses suggest that the depositionexhumation trajectory of the Vinchina Basin occurred in a time interval of $\sim 16 \mathrm{myr}$ in the Los Colorados section, which seems not to be enough to restore the steady state thermal field. 
[38] Even considering a blanketing effect with reductions of $20 \%$ in the Neogene heat flow, maximum steady state values related to the burial of the Vinchina Basin would still be extremely low (between $\sim 40$ and $51 \mathrm{~mW} \mathrm{~m}^{-2}$ ). It is important to note that the average heat flow transferred by decay of crustal radiogenic isotopes is $\sim 40 \mathrm{~mW} \mathrm{~m}^{-2}$ [Turcotte and Schubert, 2002]. This flux value matches relatively well with our results, suggesting that the thermal transport from the mantle was extremely low (up to $11 \mathrm{~mW}$ $\mathrm{m}^{-2}$ ), and is in agreement with a relative cold foreland scenario resting on a refrigerated lithosphere. Such a situation is common in shields and old cratons but can also be explained by elimination of the mantle wedge during a slab shallowing stage in subduction. Given that this basin would have developed at the foothill of the Early Miocene Andes, we prefer a flat subduction scenario to explain the low geotherm. This is also coherent with geological, geophysical and geochemical studies from the Oligocene to Present [Yáñez et al., 2001; Kay and Mpodozis, 2002; Dávila et al., 2004].

[39] The thermal modeling of the Vinchina Basin, developed to fit the dynamics of the subduction history (Figures $7 \mathrm{a}$ and $8 \mathrm{a}$ ), shows maximum temperatures $\left(135-150^{\circ} \mathrm{C}\right.$ in the Cordón de la Flecha and $210-225^{\circ} \mathrm{C}$ in Sierra de los Colorados) exceeding the temperatures documented by the preservation of expandable clay mineral phases in the bottom of the successions $\left(<120^{\circ} \mathrm{C}\right)$ and from detrital thermochronological studies [Coughlin, 2002]. The alternative of considering that the isotherms of Gutscher et al. [2000a] should be placed lower, which would drive to a decline in the thermal gradient and consequently in the heat flow (Figures $7 \mathrm{~b}$ and $8 \mathrm{~b}$ ), seems to fit with the evolution of the basin at Cordón de la Flecha section but, even reducing the heat flow values by $\sim 25 \%$, modeled temperatures for the bottom of the Vinchina Basin at Sierra de los Colorados are still higher, between 150 and $165^{\circ} \mathrm{C}$. A third alternative result of the PetroMod thermal model is shown in Figures 7c and $8 \mathrm{c}$, where we run the experiment considering the region behaved as a transitional subduction scenario between 8 and 3.4 Ma. If this were the case, the steady state thermal regime would have not been completely restored at the moment of the exhumation of the sedimentary sequence. This model supplied maximum temperatures between 105 and $120^{\circ} \mathrm{C}$ at $7 \mathrm{Km}$ depth in Sierra de los Colorados, which are consistent with the temperatures recorded through clay mineralogy. Consequently, the best fit to explain the evolution of both sections is to consider a decline in the thermal gradient proposed by Gutscher et al. [2000a] and an incomplete recovery of normal subduction geometry, at least until the exhumation of the basin (Figures $7 \mathrm{~d}$ and $8 \mathrm{~d}$ ). The models also allow discarding the influence of an old lithosphere on the Neogene thermal regime, given that average heat flow values for Proterozoic and Early Paleozoic terranes vary between 49 and $61 \mathrm{~mW} \mathrm{~m}^{-2}$ [Pollack et al., 1993; Rudnick et al., 1998] and are too high when compared with our results.

[40] The inferred thermal regime, with extremely low-heat flow values between $\sim 20$ and $\sim 30 \mathrm{~mW} / \mathrm{m}^{2}$, may be due to the fact that the average subduction dip in this region of the Central Andes is the lowest among all other subductionrelated forelands ( $300 \mathrm{~km}$ subhorizontal slab at $80 \mathrm{~km}$ depth [Gutscher et al., 2000a, 2000b; Syracuse and Abers, 2006]).
In these flat-slab regions the thermal structure of the margin is completely altered with cold oceanic lithosphere beneath the upper lithosphere, where typically hot asthenosphere is present.

[41] Further evaluation of the steady state and transient heat flow regimes elsewhere along the Andean region, both in exhumed and still buried Miocene to present successions, may allow reinforcing our interpretation and testing the control of flat-slab segments in low-heat flows and refrigerated temperatures. We also expect to analyze the influence of groundwater in the modern basin, like the Chacoparanaense Basin (M. Bonich, manuscript in preparation, 2011), in order to account for the geotherm reduction by groundwater flow.

\section{Conclusions}

[42] The location of the Vinchina Basin is within a suggested flat subduction segment of the Andean thrust belt and broken foreland during the Miocene [cf. Kay et al., 1988; Kay and Mpodozis, 2002; Dávila et al., 2004]. The cold burial history is consistent with the absence of an astenosphere wedge below the crust here. Consequently, it is reasonable to infer that the very low geothermal gradient could be associated with refrigeration of the lithosphere, related to the decreasing volume of the astenospheric wedge [Dumitru, 1991], with the flattening process contributing to declining bulk heat flux. Progressive transformations in the ordering of the clay fraction within a thick geochronologically constrained foreland basin stratigraphy in the Central Andes, aides our understanding of burial history and thermal maturity within a flat-slab subduction segment. Low-heat flows and a refrigerated lithosphere under the exhumed stratigraphy of the Vinchina Basin, considered a strongly subsiding depozone, and the same, still buried, equivalent stratigraphy analyzed from exploration wells further south in the Bermejo Basin are interpreted to be strongly controlled by the geometry of subduction and the lack of a significant astenospheric wedge.

[43] Despite the extraordinary thickness of the studied synorogenic alluvial succession, our results show an incomplete illitization prograde process typical of an incipient burial in an immature cold basin. Persistence of $\mathrm{R} 0$ clay ordering at $>6 \mathrm{~km}$ depth is consistent with previous thermochronologic studies indicating very low geothermal gradients, $\sim 15^{\circ} \mathrm{C} / \mathrm{km}$, and maximum temperatures under $120^{\circ} \mathrm{C}$. Although low paleogeothermal gradients have been attributed to varying accumulation/unroofing rates or deformation processes, according to our interpretation the geometry of subduction seems to be the principal factor controlling heat flow and thermal maturity in the Vinchina Basin and perhaps in other analogous retroforeland sedimentary basins.

[44] Acknowledgments. We are grateful to the Consejo Nacional de Investigaciones Científicas y Técnicas, the Agencia Nacional de Promoción de Ciencia y Tecnología, and the Secretaría de Ciencia y Tecnología of the Universidad Nacional de Córdoba that support our research projects in west Argentina. We would like to acknowledge Fernando Nieto García and Christopher Schmidt for their constructive reading of the paper. SEM and TEM analyses were performed in the Centro de Intrumentación Científica, Universidad de Granada, with the financial support of the Agencia Española de Cooperación Internacional and the Ministerio de 
Educación y Ciencia de España. The authors are also thankful for the help of M. M. Abad-Ortega with the TEM and AEM and I. Guerra Tschuschke with the SEM and EDX. The Royal Society (UK) and Marie Curie Fellowship (ERC) supported Federico M. Dávila. We also thank the very constructive reviews and comments by Teresa Jordan and Marcelo Farias and the editorial recommendations that improved this work.

\section{References}

Abid, I. A., R. Hesse, and J. D. Harper (2004), Variations in mixed-layer illite/smectite diagenesis in the rift and post-rift sediments of the Jeanne d'Arc Basin, Grand Banks offshore Newfoundland, Canada, Can. J. Earth Sci., 41, 401-429, doi:10.1139/e04-004.

Allen, P. A., and J. R. Allen (2005), Basin Analysis: Principles and Applications, 2nd ed., Blackwell, Malden, Mass.

American Association of Petroleum Geologists (1976), Basic data file from AAPG Geothermal Survey of North America, report, Univ. of Okla., Norman.

Anderson, M., P. Alvarado, G. Zandt, and S. Beck (2007), Geometry and brittle deformation of the subducting Nazca plate, Central Chile and Argentina, Geophys. J. Int., 171(1), 419-434, doi:10.1111/ j.1365-246X.2007.03483.x

Astini, R. A., F. Martina, M. Ezpeleta, F. M. Dávila, and P. Cawood (2009), Chronology from rifting to foreland basin in the Paganzo Basin (Argentina), and a reapprisal on the "Eo- and Neohercynian" tectonics along western Gondwana, paper presented at 12th Chilean Geological Congress, Geol. Soc. of Chile, Santiago.

Awwiller, D. N. (1993), Illite-Smectite formation and potassium mass transfer during burial diagenesis of mudrocks: A study from the Texas Gulf-Coast Paleocene-Eocene, J. Sediment. Petrol., 63, 501-512.

Barazangi, M., and B. Isacks (1976), Spatial distribution of earthquakes and subduction of the Nazca plate beneath South America, Geology, 4, 686-692, doi:10.1130/0091-7613(1976)4<686:SDOEAS $>2.0$. CO;2.

Beer, J. A., and T. E. Jordan (1989), The effects of Neogene thrusting on deposition in the Bermejo basin, Argentina, J. Sediment. Petrol., 59, 330-345.

Berger, G., J.-C. Lacharpagne, B. Velde, D. Beaufort, and B. Lanson (1997), Kinetic constrains on illitization reactions and the effects of organic diagenesis in sandstone/shale sequences, Appl. Geochem., 12, 23-35, doi:10.1016/S0883-2927(96)00051-0.

Borrello, A., and A. Cuerda (1968), Grupo Río Huaco (Triásico), San Juan. Comisión de Investigaciones Científicas de la provincia de Buenos Aires, Noticias, 7, 3-15.

Cahill, T., and B. L. Isacks (1992), Seismicity and shape of the subducted Nazca plate, J. Geophys. Res., 97, 17,503-17,529, doi:10.1029/ 92JB00493.

Cardozo, N., and T. E. Jordan (2001), Causes of spatially variable tectonic subsidence in the Miocene Bermejo Foreland Basin, Argentina, Basin Res., 13, 335-357, doi:10.1046/j.0950-091x.2001.00154.x.

Carrapa, B., D. Adelmann, G. E. Hilley, E. Mortimer, E. Sobel, and M. R. Strecker (2005), Oligocene range uplift and development of plateau morphology in the southern central andes, Tectonics, 24, TC4011, doi:10.1029/2004TC001762.

Carrapa, B., M. R. Strecker, and E. R. Sobel (2006), Cenozoic orogenic growth in the Central Andes: Evidence from sedimentary rock provenance and apatite fission track thermochronology in the Fiambalá Basin, southernmost Puna Plateau margin (NW Argentina), Earth Planet. Sci. Lett., 247, 82-100, doi:10.1016/j.eps1.2006.04.010.

Carrapa, B., J. Hauer, L. Schoenbohm, M. R. Strecker, A. K. Schmitt, A. Villanueva, and J. Sosa Gomez (2008), Dynamics of deformation and sedimentation in the northern Sierras Pampeanas: An integrated study of the Neogene Fiambalá basin, NW Argentina, Geol. Soc. Am. Bull., 120, 1518-1543, doi:10.1130/B26111.1.

Champness, P. E., G. Cliff, and G. W. Lorimer (1981), Quantitative analytical electron microscopy, Bull. Mineral., 104, 236-240.

Ciccioli, P. L., C. Limarino, and S. A. Marenssi (2005), Nuevas edades radimétricas para la Formación Toro Negro en la sierra de Los Colorados, Sierras Pampeanas Noroccidentales, provincia de La Rioja, Asoc. Geol. Argent. Rev., 60, 251-254.

Ciccioli, P. L., C. O. Limarino, S. A. Marenssi, A. M. Tedesco, and A. Tripaldi (2008), Estratigrafía de la cuenca de Vinchina, Sierras Pampeanas noroccidentales, noroeste de la provincia de La Rioja, Actas del XVII Congreso Geológico Argentino, pp. 343-344, Asoc. Geol. Argent., Buenos Aries.

Cliff, G., and G. W. Lorimer (1975), The quantitative analysis of thin specimens, J. Microsc., 103, 203-207.

Collo, G., and F. M. Dávila (2008), Burial history and estimation of ancient thermal gradients in deep synorogenic foreland sequences: The Neogene
Vinchina basin, South-Central Andes, paper presented at 7th International Symposium on Andean Geodynamics, Univ. de Nice Sophia Antipolis, Paris, 2-4 Sept

Collo, G., F. M. Dávila, and R. A. Astini (2010), Clay minerals evolution and thermal burial history of the Neogene Bermejo foreland basin, southCentral Andes, paper presented at 18th International Sedimentological Congress, Int. Assoc. of Sedimentol., Mendoza, Argentina.

Coughlin, T. J. (2002), Linked origen-oblique fault zones in the Central Argentine Andes: The basis of a new model for Andean orogenesis and metallogenesis, Ph.D. thesis, Univ. of Queensl., Brisbane, Queensl., Australia.

Coutand, I., B. Carrapa, A. Deeken, A. K. Schmitt, E. R. Sobel, and M. R. Strecker (2006), Propagation of orographic barriers along an active range front: Insights fromsandstone petrography and detrital apatite fission-track thermochronology in the intramontane Angastaco basin, NW Argentina, Basin Res., 18, 1-26, doi:10.1111/j.1365-2117.2006.00283.x.

Cuadros, J., and J. Linares (1996), Experimental kinetic study of the smectite-to-illite transformation, Geochim. Cosmochim. Acta, 60, 439-453, doi:10.1016/0016-7037(95)00407-6.

Dávila, F. M., and R. A. Astini (2003a), Early middle Miocene broken foreland development in the southern central Andes: Evidence for extension prior to regional shortening, Basin Res., 15, 379-396, doi:10.1046/ j.1365-2117.2003.00206.x.

Dávila, F.M., and R.A. Astini (2003b), Las eolianitas de la sierra de Famatina (Argentina): Interacción paleoclima-tectónica en el antepaís fragmentado andino central durante el Mioceno Medio?, Rev. Geol. Chile, 30(2), 187-204.

Dávila, F. M., and R. A. Astini (2007), Cenozoic provenance history of synorogenic conglomerates in western Argentina (Famatina belt): Implications for Central Andean foreland development, Geol. Soc. Am. Bull., 119, 609-622, doi:10.1130/B26007.1.

Dávila, F. M., R. A. Astini, T. E. Jordan, and S. M. Kay (2004), Early Miocene andesite conglomerates in the Sierra de Famatina, broken foreland region of western Argentina, and documentation of magmatic broadening in the south-central Andes, J. South Am. Earth Sci., 17, 89-101, doi:10.1016/j.jsames.2004.04.001.

Dávila, F. M., R. A. Astini, and T. E. Jordan (2005), Cargas subcorticales en el antepaís andino y la planicie pampeana: Evidencias estratigráficas, topográficas y geofísicas, Asoc. Geol. Argent. Rev., 60, 775-786.

Dávila, F. M., R. A. Astini, T. E. Jordan, G. Gehrels, and M. Ezpeleta (2007), Miocene forebulge development previous to the broken foreland partitioning in the southern Central Andes, west-central Argentina, Tectonics, 26, TC5016, doi:10.1029/2007TC002118.

Dávila, F. M., G. Collo, R. A. Astini, and G. Gehrels (2008), U-Pb detrital ages on a tuffaceous sandstone sheet in the Vinchina Formation, La Rioja, Argentina: Deposition and exhumation implications, Actas del XVII Congreso Geológico Argentino, pp. 95-96, Asoc. Geol. Argent., Buenos Aries.

Dávila, F. M., C. Lithgow-Bertelloni, and M. Giménez (2010), Tectonic and dynamic controls on the topography and subsidence of the Argentine Pampas: The role of the flat slab, Earth Planet. Sci. Lett., 295, 187-194, doi:10.1016/j.epsl.2010.03.039.

DeCelles, P. G., and K. A. Giles (1996), Foreland basin systems, Basin Res., 8, 105-123, doi:10.1046/j.1365-2117.1996.01491.x.

Deming, D. (1994), Fluid flow and heat transport in the upper continental crust, in Geofluids: Origin, Migration and Evolution of Fluids in Sedimentary Basins, edited by J. Parnel, Geol. Soc. Spec. Publ., 78, 27-42.

Dorsey, R. J., E. J. Buchovecky, and N. Lundberg (1988), Clay mineralogy of Pliocene-Pleistocene mudstones, eastern Taiwan: Combined effects of burial diagenesis and provenance unroofing, Geology, 16, 944-947, doi:10.1130/0091-7613(1988)016<0944:CMOPPM>2.3.CO;2.

Dumitru, T. A. (1991), Effects of subduction parameters on geothermal gradients in forearcs, with an application to Franciscan subduction in California, J. Geophys. Res., 96, 621-641, doi:10.1029/90JB01913.

Eberl, D. D., and J. Hower (1976), Kinetics of illite formation, Geol. Soc. Am. Bull., 87, 1326-1330, doi:10.1130/0016-7606(1976)87<1326: $\mathrm{KOIF}>2.0 . \mathrm{CO} ; 2$.

Fauque, L., and R. Caminos (2006), Hoja geológica 2969-II Tinogasta, pcias de La Rioja, Catamarca y San Juan, Bol. Argent., Serv. Geol. Nac., 276

Frey, M., and D. Robinson (1999), Low Grade Metamorphism, Blackwell Sci, Cambridge, U. K.

Furque, G. (1972), Descripción Geológica de la hoja 16b, Cerro La Bolsa, Provincias de La Rioja y San Juan, Argent. Dir. Nac. Geol. Min. Bol., $125,1-70$.

Gleadow, A. J. W., and I. R. Duddy (1981), A natural long-term track annealing experiment for apatite, Nucl. Tracks, 5, 169-174, doi:10.1016/ 0191-278X(81)90039-1. 
Guidotti, C. V., M. G. Yates, M. D. Dyar, and M. E. Taylor (1994), Petrogenetic implications of the $\mathrm{FeH}$ content of muscovite in pelitic schists, Am. Mineral., 79, 793-795.

Gutscher, M.-A. (2002), Andean subduction styles and their effects in thermal structure and intraplate coupling, J. South Am. Earth Sci., 15, 3-10, doi:10.1016/S0895-9811(02)00002-0.

Gutscher, M.-A., R. Maury, J.-P. Eissen, and E. Bourdon (2000a), Can slab melting be caused by flat subduction?, Geology, 28, 535-538, doi:10.1130/0091-7613(2000)28<535:CSMBCB >2.0.CO;2.

Gutscher, M.-A., W. Spakman, H. Bijwaard, and E. R. Engdahl (2000b), Geodynamics of flat subduction: Seismicity and tomographic constraints from the Andean margin, Tectonics, 19, 814-833, doi:10.1029/ 1999TC001152.

Hamza, V. M., F. J. S. Silva Dias, A. J. L. Gomes, and Z. G. Delgadilho Terceros (2005), Numerical and functional representations of regional heat flow in South America, Phys. Earth Planet. Inter., 152, 223-256, doi:10.1016/j.pepi.2005.04.009

Henry, S. G., and H. N. Pollack (1988), Terrestrial heat flow above the Andean subduction zone in Bolivia and Peru, J. Geophys. Res., 93, 15,153-15,162, doi:10.1029/JB093iB12p15153.

Hoffman, J., and J. Hower (1979), Clay mineral assemblages as low grade metamorphic geothermometers: Application to the thrust faulted disturbed belt of Montana, U. S. A., in Aspects of Diagenesis, edited by P. A. Scholle and P. R. Schluger, Spec. Publ. Soc. Econ. Paleontol. Mineral., 26, 55-79.

Hower, J., E. V. Eslinger, M. E. Hower, and E. A. Perry (1976), Mechanism of burial metamorphism of argillaceous sediment: 1. Mineralogical and chemical evidence, Geol. Soc. Am. Bull., 87, 725-737, doi:10.1130/ 0016-7606(1976)87<725:MOBMOA>2.0.CO;2.

Husson, L., and S. Moretti (2002), Thermal regime of fold and thrust belts-An application to the Bolivian sub Andean zone, Tectonophysics, 345, 253-280, doi:10.1016/S0040-1951(01)00216-5.

Jagodzinski, H. (1949), Einss dimensionale felhordnung in kristallen und ihr einflu auf die röntgeninterferenzen. III. Vergleich der Berechnungen mit Experimentellen Ergebnissen, Acta Crystallog., 2, 298-304, doi:10.1107/S0365110X49000771.

Jennings, S., and G. R. Thompson (1986), Diagenesis of Plio-Pleistocene sediments of the Colorado River Delta, southern California, J. Sediment. Petrol., 56, 89-98.

Jordan, T. E., P. Zeitler, V. A. Ramos, and A. J. W. Gleadow (1989), Thermochronometric data on the development of the basement peneplain in the Sierras Pampeanas, Argentina, J. South Am. Earth Sci. 2(3), 207-222, doi:10.1016/0895-9811(89)90030-8

Jordan, T. E., R. W. Allmendinger, J. F. Damanti, and R. E. Drake (1993), Chronology of motion in a complete thrust belt: The Precordillera, $30^{\circ}-31^{\circ}$, Andes Mountain, J. Geol., 101, 135-156, doi:10.1086/648213.

Jordan, T. E., F. Schlunegger, and N. Cardozo (2001), Unsteady and spatially variable evolution of the Neogene Andean Bermejo foreland basin, Argentina, J. South Am. Earth Sci., 14, 775-798, doi:10.1016/S08959811(01)00072-4

Kay, S. M., and C. Mpodozis (2002), Magmatism as a probe to the Neogene shallowing of the Nazca plate beneath the modern Chilean flatslab, J. South Am. Earth Sci., 15, 39-57, doi:10.1016/S08959811(02)00005-6.

Kay, S. M., V. Maksaev, R. Moscoso, C. Mpodozis, C. Nasi, and C. E. Gordillo (1988), Tertiary Andean magmatism in Chile and Argentina between $28^{\circ} \mathrm{S}$ and $32^{\circ} \mathrm{S}$ : Correlation of magmatic chemistry with a changing Benioff zone, J. South Am. Earth Sci., 1, 21-38, doi:10.1016/0895-9811(88)90013-2.

Lanson, B. (1997), Decomposition of experimental X-Ray diffraction patterns (Profile fitting) a convenient way to study clay minerals, Clays Clay Miner., 45(2), 132-146, doi:10.1346/CCMN.1997.0450202.

Lanson, B., and B. Velde (1992), Decomposition of X-ray diffraction patterns: A convenient way to describe complex I/S diagenetic evolution, Clays Clay Miner., 40(6), 629-643, doi:10.1346/CCMN.1992.0400602.

Lencinas, R. (1994), Los depósitos pleistocenos-holocenos del valle de Famatina, La Rioja, Argentina, 7th Congreso Geológico Chileno, vol. 1, pp. 465-470, Univ. de Chile, Santiago.

Limarino, C., A. Tripaldi, S. Marenssi, L. Net, G. Re, and A. Caselli (2001), Tectonic control on the evolution of fluvial systems of the Vinchina Formation (Miocene), northwestern Argentina, J. South Am. Earth Sci., 14, 751-762, doi:10.1016/S0895-9811(01)00067-0.

Lindgreen, H. (1991), Elemental and structural changes in illite/smectite mixed-layer clay minerals during diagenesis in Kimmeridgian-Volgian (-Ryazanian) clays in the Central Trough, North Sea and the NorwegianDanish Basin, Bull. Geol. Soc. Den., 39, 1-82.

Löbens, S., F. A. Bense, K. Wemmer, I. Dunkl, C. H. Costa, P. Layer, and S. Siegesmund (2011), Exhumation and uplift of the Sierras Pampeanas: Preliminary implications from K-Ar fault gouge dating and low-T ther- mochronology in the Sierra de Comechingones (Argentina), Int. J. Earth Sci., 100, 671-694(Geol Rundsch), doi:10.1007/s00531-010-0608-0.

Lucazeau, F., and S. L. Le Douaran (1985), The blanketing effect of sediments in basins formed by extension: A numerical model. Application to the Gulf of Lion and Viking graben, Earth Planet. Sci. Lett., 74, 92-102, doi:10.1016/0012-821X(85)90169-4

Merriman, R. J., and D. R. Peacor (1999), Very low-grade metapelites: Mineralogy, microfabrics and measuring reaction progress, in Low-Grade Metamorphism, edited by M. Frey and D. Robinson, pp. 10-60, Blackwell Sci., Oxford, U. K.

Moore, D. M., and R. C. Reynolds (1997), X-Ray Diffraction and the Identification and Analysis of Clay Minerals, Oxford Univ. Press, New York.

Muñoz, M. (2005), No flat Wadati-Benioff Zone in the central and southern central Andes, Tectonophysics, 395, 41-65, doi:10.1016/j. tecto.2004.09.002

Muñoz, M., and V. M. Hamza (1996), Maps of terrestrial heat flow density distribution in South America, paper presented at the 3rd Internationa Symposium on Andean Geodynamics, Off. de la Rech. Sci. et Tech. d'Outre-Mer, St Malo, France.

Naeser, C. W. (1979), Fission-track dating and geologic annealing of fission tracks, in Lectures in isotope geology, edited by E. Jager and J. C. Hunziker, pp. 154-169, Springer, Berlin

Naeser, S. W. (1981), The fading of fission tracks in the geologic environment: Data from deep drill holes, Nucl. Tracks Radiat. Meas., 5, 248-250.

Nalpas, T., G. Herail, C. Mpodozis, R. Riquelme, J. Clavero, and M. P. Dabard (2005), Thermochronological data and denudation history along a transect between chanaral and pedernales $\left(-26^{\circ} \mathrm{s}\right)$, north Chilean Andes: Orogenic implication, paper presented at the 6th International Symposium on Andean Geodynamics, Univ. de Barcelona, Barcelona. Spain.

Nieto, F., M. Ortega-Huertas, D. R. Peacor, and J. Arostegui (1996), Evolution of illite/smectite from early diagenesis through incipient metamorphism in sediments of the Basque-Cantabrian Basin, Clays Clay Miner. 44(3), 304-323, doi:10.1346/CCMN.1996.0440302.

Nóbile, J., G. Collo, and F. M. Dávila (2008), Transformación progresiva de minerales de arcilla durante el soterramiento de la cuenca de Vinchina (Mioceno Tardio-Plioceno), Sierras de los Colorados, La Rioja, paper presented at the 12th Reunión Argentina de Sedimentología, Asoc. Argent. de Sedimentol., Buenos Aires.

Pardo, M., D. Comte, and T. Monfret (2002), Seismotectonic and stress distribution in the central Chile subduction zone, J. South Am. Earth Sci., 15, 11-22, doi:10.1016/S0895-9811(02)00003-2.

Pollack, H. N., S. J. Hurter, and J. R. Johnston (1993), Heat loss from the earth's interior: Analysis of the global data set, Rev. Geophys., 31, 267-280, doi:10.1029/93RG01249.

Pollastro, R. M. (1993), Considerations and applications of the illite/ smectite geothermometer in hydrocarbon-bearing rocks of Miocene to Missisippian Age, Clays Clay Miner., 41, 119-133, doi:10.1346/ CCMN.1993.0410202.

Ramos, V. (1999), Los depósitos sinorogénicos terciarios de la región andina, in Geología Argentina, vol. 29, edited by R. Caminos, pp. 651-691, Inst. Geol. Recur. Miner., Buenos Aires.

Ramos, V., J. Reynolds, T. Jordan, and K. D. Tabbutt (1988), Time constraints for the uplift of the Sierras de Toro Negro, Umango and Espinal, Western Sierras Pampeanas, Argentina, Geol. Soc. Am. Abstr. Programs, 20(7), A61

Ramos, V. A. (1970), Estratigrafía y estructura del Terciario en la sierra de los Colorados (Provincia de La Rioja), República Argentina, Asoc. Geol. Argent. Rev., 25(3), 359-382.

Re, G. H., and S. P. Barredo (1993), Esquema de correlaciones de las formaciones terciarias aflorantes en el entorno de las Sierras Pampeanas y la Precordillera Argentina, in Geologia y recursos naturales de Mendoza: XII Congreso Geológico Argentino y II Congreso de Exploración de Hidrocarburos, actas 2, edited by V. A. Ramos, pp. 172-179, La Comisión, Buenos Aires.

Reynolds, J. H., T. E. Jordan, N. M. Johnson, J. F. Damanti, and K. D. Tabbutt (1990), Neogene deformation of the flat-subduction segment of the Argentine-Chilean Andes: Magnetostratigraphy constraints from Las Juntas, La Rioja Province, Argentina, Geol. Soc. Am. Bull., 102, 1607-1622, doi:10.1130/0016-7606(1990)102<1607:NDOTFS $>2.3$. $\mathrm{CO} ; 2$.

Rodríguez Brizuela, R., and A. Tauber (2006), Estratigrafía y mamíferos fósiles de la Formación Toro Negro (Neógeno), Departamento Vinchina, noroeste de la provincia de La Rioja, Argentina, Ameghiniana, 43(2), 257-272.

Rudnick, R. L., W. F. McDonough, and R. J. O'Connell (1998), Thermal structure, thickness and composition of continental lithosphere, Chem Geol., 145, 395-411, doi:10.1016/S0009-2541(97)00151-4.

Sobel, E. R., and M. R. Strecker (2003), Uplift, exhumation and precipitation: Tectonic and climatic control of Late Cenozoic landscape evolution 
in the northern Sierras Pampeanas, Argentina, Basin Res., 15, 431-451, doi:10.1046/j.1365-2117.2003.00214.x.

Springer, M., and A. Förster (1998), Heat-flow density across the Central Andean subduction zone, Tectonophysics, 291, 123-139, doi:10.1016/ S0040-1951(98)00035-3.

Srodon, J. Y., and D. D. Eberl (1984), Illite, in Reviews in Mineralogy, vol. 13, edited by S. W. Bailey, pp. 495-544, Miner. Soc. of Am. Washington, D. C.

Sucha, V., I. Kraus, H. Gerthofferva, J. Petes, and M. Serekova (1993), Smectite to illite conversion in bentonites and shales of the East Slovak Basin, Clay Miner., 28, 243-253, doi:10.1180/claymin.1993.028.2.06.

Syracuse, E. M., and G. A. Abers (2006), Global compilation of variations in slab depth beneath arc volcanoes and implications, Geochem. Geophys. Geosyst., 7, Q05017, doi:10.1029/2005GC001045.

Tabbutt, K. D. (1986), Fission track chronology of foreland basins, in the eastern Andes: Magmatic and tectonic implications, Ph.D. thesis, Dartmouth Coll., Hannover, N. H.

Tabbutt, K. D., C. W. Naeser, T. E. Jordan, and P. F. Cerveny (1989), New fission-track ages of Mio-Pliocene tuffs in the Sierras Pampeanas and Precordillera of Argentina, Asoc. Geol. Argent. Rev., 44 408-419.

Tedesco, A. M. (2006), Estratigrafia, evolución paleoambiental y tectosedimentaria de la Cuenca de La Troya (Paleógeno y Neógeno, Precordillera de La Rioja), Ph.D. thesis, Univ. de Buenos Aires, Buenos Aires.

Tripaldi, A., L. Net, C. Limarino, S. Marenssi, G. Re, and A. Caselli (2001), Paleoambientes sedimentarios y procedencia de la Formación Vinchina, Mioceno, noroeste de la provincia de La Rioja, Asoc. Geol. Argent. Rev., 56(4), 443-465.

Turcotte, D. L., and G. Schubert (2002), Geodynamics, 2nd ed., Cambridge Univ. Press, New York.
Turner, J. C. M. (1964), Descripción geológica de la hoja 15 c Vinchina (Provincia de La Rioja), in Carta Geológico-Económica de la República Argentina, Escala 1: 200.000, Argent., Dir. Nac. Geol. Min., Bol., 100, $81 \mathrm{pp}$.

Uysal, I. T., M. Glikson, S. D. Golding, and F. Audsley (2000), The thermal history of the Bowen Basin, Queensland, Australia: Vitrinite reflectance and clay mineralogy of Late Permian coal measures, Tectonophysics, 323, 105-129, doi:10.1016/S0040-1951(00)00098-6.

Velde, B., and G. Vasseur (1992), Estimation of the diagenetic smectite to illite transformation in time-temperature space, Am. Mineral., 77, 967-976.

Weaver, C. E. (1989), Clays, Muds, and Shales, Dev. Sedimentol., vol. 44, Elsevier, New York.

Yáñez, G. A., C. R. Ranero, R. Von Huene, and J. Díaz (2001), Magnetic anomaly interpretation across the southern central Andes $\left(32^{\circ}-34^{\circ} \mathrm{S}\right)$ : The role of the Juan Fernández Ridge in the late Tertiary evolution of the margin, J. Geophys. Res., 106, 6325-6345, doi:10.1029/2000JB900337.

Zambrano, O., A. E. Rapalini, F. M. Dávila, R. A. Astini, and C. M. Spagnuolo (2011), Magnetostratigraphy and paleomagnetism of the Early Del Crestón Formation (Famatina, Argentina) and its implications in the evolution of the Andean broken foreland, Int. J. Earth Sci., 100, 591-602.

R. A. Astini, G. Collo, F. M. Dávila, and J. Nóbile, Laboratorio de Análisis de Cuencas, CICTERRA-Universidad Nacional de Córdoba, Av. Velez Sarsfield 1611, $2^{\circ}$ Piso, Oficina 7, X5016GCA Córdoba, Argentina. (gcollo@efn.uncor.edu)

G. Gehrels, Department of Geosciences, University of Arizona, GouldSimpson Bldg. 77, 1040 E. 4th St., Tucson, AZ 85721, USA. 